\title{
Geochemistry of Tikak Parbat Sandstones and Tipam Sandstones Occurring in and around Dilli Area, Sivasagar District, Assam, India
}

\author{
Hrishikesh Baruah'1, Asim Dutta Lahkar', Balen Bhagabati², Ranjeeta Kar',2, Pradip Kumar Das ${ }^{2}$ \\ ${ }^{1}$ Department of Geology, Arya Vidyapeeth College, Guwahati, India \\ ${ }^{2}$ Department of Geological Sciences, Gauhati University, Guwahati, India \\ Email: hbaruah@hotmail.com
}

How to cite this paper: Baruah, H., Lahkar, A.D., Bhagabati, B., Kar, R. and Das, P.K. (2017) Geochemistry of Tikak Parbat Sandstones and Tipam Sandstones Occurring in and around Dilli Area, Sivasagar District, Assam, India. Open Journal of Geology, 7, 1238-1267.

https://doi.org/10.4236/ojg.2017.78083

Received: July 18, 2017

Accepted: August 25, 2017

Published: August 28, 2017

Copyright (c) 2017 by authors and Scientific Research Publishing Inc. This work is licensed under the Creative Commons Attribution International License (CC BY 4.0).

http://creativecommons.org/licenses/by/4.0/

\begin{abstract}
This study presents a geochemical investigation of Tikak Parbat and Tipam Sandstone Formations occurring in and around Dilli area, Sivasagar, Assam. Petrographically Tikak Parbat and Tipam sandstones are mainly quartzose arenite to sublitharenite types with their constituents being derived from recycled orogen provenance under sub-humid to humid climatic conditions. Geochemically, sandstones of both the formations range from sublitharenite to wacke. They indicate a recycled orogen source and influence of humid to arid condition. Source rocks of Tikak Parbat sandstones were more weathered than the Tipam sandstones. While Tikak Parbat sandstones show affinity towards passive margin, Tipam sandstones hint at active continental margin setup, where clasts were supplied from uplifted areas. Upliftment of provenance covering areas of Naga Patkai Range in the south east and Eastern Himalayas along the syntaxial bend during mid Miocene affected the sandstones. Tikak Parbat sandstones reflect a stable tectonic setup which later underwent a phase of volatility leading to deposition of the Tipam sandstones. Our study supports a sediment supply from the upper continental crust, largely of granitic composition, however, with a significant variation in their depth of source supply. Trace element analyses indicate depositional setup with low ventilation marked by both oxic and anoxic phases.
\end{abstract}

\section{Keywords}

Geochemistry, Provenance, Palaeoweathering, Tikak Parbat Sandstones, Tipam Sandstones, Dilli (Assam, India) 


\section{Introduction}

Physical examinations of sedimentary rocks and subsequent provenance analyses have been priority research domains in the field of sedimentological studies. Such attempts mostly aim to reconstruct the pre-depositional history of a sediment or sedimentary rock which includes observations on the distance and direction of the provenance, type, size and setting of the source region, climate and relief in the source area, and the specific type of sedimentary rocks [1] [2] [3] [4]. Applications of sophisticated geochemical techniques provide robust support and have further widened the scope of sedimentological studies like predepositional evolution of the source terrain, source rock and depositional environment evaluation, palaeoweathering and redox analyses of sediments etc. [5]-[12]. Geochemical investigations are advantageous as they can be carried out on sedimentary rocks of variable grain size and even in mineralogically altered rocks. Geochemical data are usually sub-divided into four categories: major elements, trace elements, radiogenic isotopes and stable isotopes. The status and trends of these four categories throw some light on the geological background of the rocks.

In the present study an attempt has been made to mainly ascertain some geochemical attributes of two important lithostratigraphic units of the Assam-Arakan basin: Tikak Parbat sandstones and Tipam sandstones exposed in and around Dilli-Jeypore coalfield of Upper Assam. Assam-Arakan tectono-sedimentary basin is situated in the north eastern part of India and it is the largest onshore receptacle of Palaeogene-Neogene rocks in India. The major tectonic elements of the basin include Assam Shelf, Belt of Schuppen and the Assam Arakan fold belt. It may be mentioned that the two units: Tikak Parbat sandstones and Tipam sandstones belong to two different ages-Oligocene and Miocene, respectively and are very important hosts of economic resources like coal and petroleum. The area of interest is a part of the Upper Assam Shelf and is in proximity of the Belt of Schuppen. Further, it may be mentioned that the hinge zone of Assam-Arakan sedimentary basin which is a shelf-slope basinal system lies below the Belt of Schuppen. The major oxides' variations, trace element and rare earth elemental concentrations were utilised to meet the objectives of reconstructing tectonic setting of depositional basin, provenance and, reveal palaeo climatic conditions and palaeoweathering of the concerned rock units of the study area. Petrographic attributes of the investigated samples are also summarized here to give an insight into their mineralogical traits.

\section{Geology of the Area}

The present study were designed to investigate a part of Dilli-Jeypore coalfield of Upper Assam and located in the foot hills of Naga-Patkai hills along the Dilli river section (Plate 1). The area at large is traversed by a linear belt of overthrusts known as "Belt of Schuppen" where Tertiary strata have been folded and dispersed into a number of thrust blocks. The Barail (Oligocene) and Tipam 

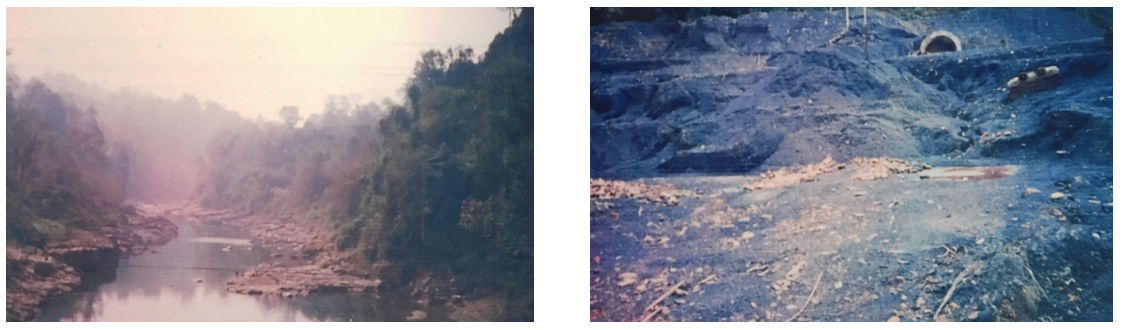

Plate 1. Panoramic view of the study area along with the coal mine (Lahkar, 2007).

(Miocene) Group of rocks are exposed in the area of study (Table 1). The study area is bounded by Lat. $27^{\circ} 04^{\prime} \mathrm{N}-27^{\circ} 09^{\prime} \mathrm{N}$ and Long. $95^{\circ} 15^{\prime} \mathrm{E}-95^{\circ} 22^{\prime} \mathrm{E}$ (Figure $1)$.

The Tikak Parbat Formation of Barail Group is well exposed in the area mostly in the hills adjoining the alluvial plains. These exposures overlie the Naga Thrust and are characterised by massive to well-bedded, fine to medium grained, yellowish to light grey and grayish white sandstones. Sandstones are characterised by two sets of joints and ripple marks. The massive sandstones are intercalated with shale and coal seams. The Naga thrust which is the north western margin of the Belt of Schuppen separates the Tikak Parbat Formation from the adjoining alluvial plains. Thickness of the Tikak Parbat sandstones range up to $20 \mathrm{mts}$. in the Dilli river section and strike is largely ENE-WSW to NE-SW dipping $35^{\circ}$ to $65^{\circ}$ towards SE. The Tipam Sandstone Formation unconformably overlies the Tikak Parbat Formation. The Tipam sandstones are characterised by fine to coarse grained texture. These sandstones which are pebbly and gritty in nature towards the base are also bedded, massive, micaceous, ferrugenous and grey coloured with salt and pepper appearance. Occasionally laminations are observed. The Tipam Formation rocks strike ENE-WSW to NE-SW and dip $35^{\circ}$ to $55^{\circ}$ towards SE (Plate 2). The regional structure of the Dilli-Jeypore coalfield is that of an anticline (commonly referred to as the Jeypore anticline). Attitude of both the units are also similar striking NE-SW and moderate to highly dipping SE.

\section{Methods}

Representative samples were collected systematically from Dilli area along traverses at regular intervals and points of lithological change from surface exposures. The exposures were mostly confined to Dilli river section, nallas and "Naga Baat" (regular walking routes of Naga tribes from neighbouring places).

Forty six representative thin sections were considered for detailed petrographic analyses where different quartz types were identified following Basu et al. [13]. Around 450 counts were made per section following the point counting technique of Chayes [14] for identifying the sandstone types.

Geochemical analyses of representative samples of Tikak Parbat sandstones and Tipam sandstones from the study area were considered to evaluate their chemical constitution with regard to major oxides and trace elements including rare earth elements. Twenty representative sandstone samples from both the 


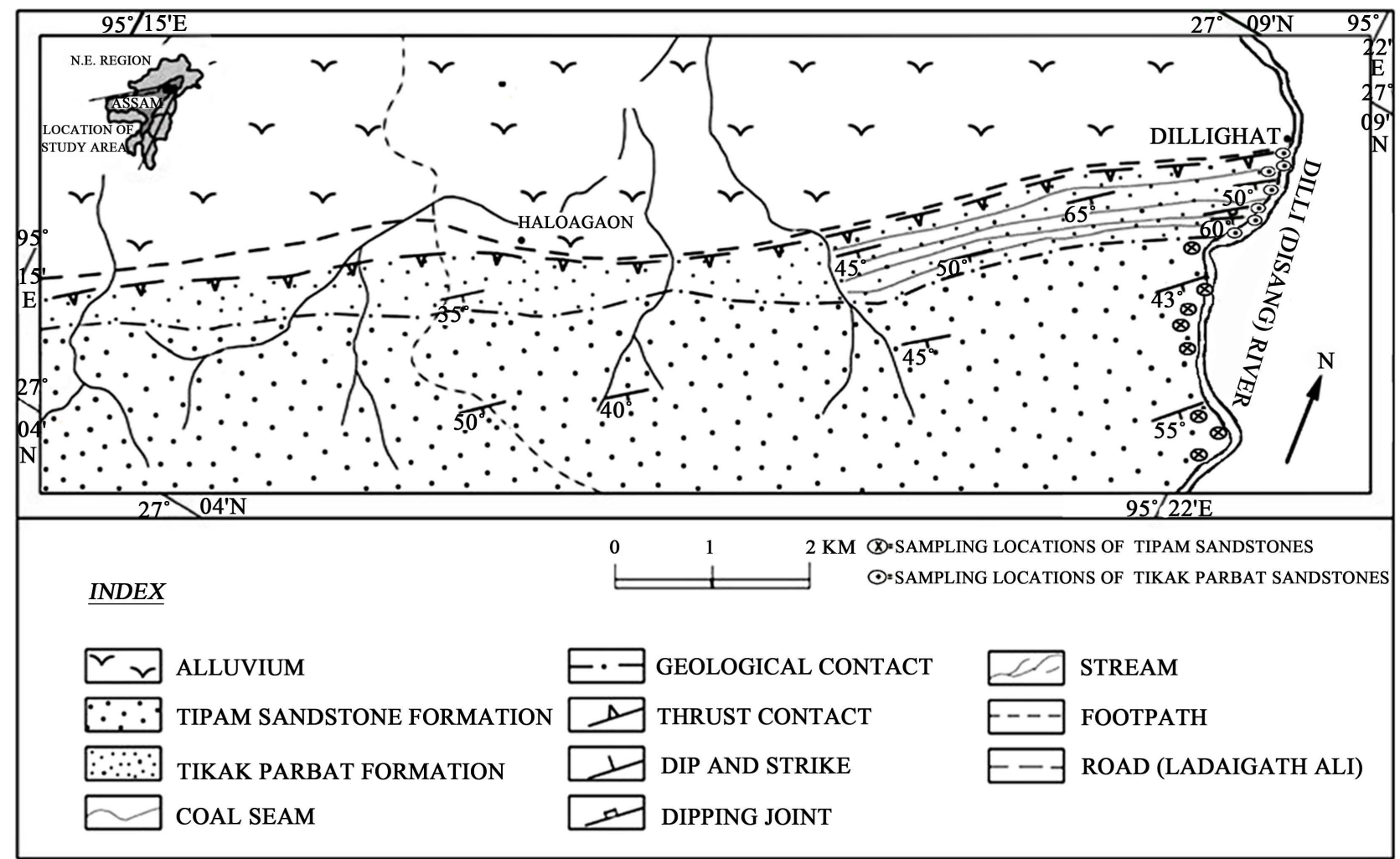

Figure 1. Geological map of the Dilli area, Sivasagar district, Assam (after Lahkar, 2007). The sample locations are marked in the map.

Table 1. Stratigraphic succession of the study area (after Lahkar, 2007).

\begin{tabular}{|c|c|c|c|}
\hline Age & Group & Formation & Lithology \\
\hline \multirow[t]{2}{*}{ Recent } & & & Alluvial soil cover with terraces \\
\hline & & & Hard grey sandstone, siltstone, shale \\
\hline \multirow[t]{4}{*}{ Miocene } & Tipam & Tipam sandstone & \\
\hline & & & $\begin{array}{l}\text { Coarse to gritty hard sandstones with } \\
\text { salt and pepper appearance. }\end{array}$ \\
\hline & & & Unconformity \\
\hline & & & $\begin{array}{l}\text { Sandstone, carbonaceous shale and coal } \\
\text { seams with shale and sandy shale. }\end{array}$ \\
\hline \multirow[t]{3}{*}{ Oligocene } & Barail & Tikak Parbat & \\
\hline & & & $\begin{array}{l}\text { Shale, carbonaceous shale, sandy shale, } \\
\text { sandstone and thick coal seam. }\end{array}$ \\
\hline & & Thrt & contact (Naga Thrust) \\
\hline
\end{tabular}

units were analysed by SIEMENS SRS 3000 XRF in Wadia Institute of Himalayan Geology, Dehradun, India for major oxides. The samples were further analysed for trace elements including rare earth elements by ICP-MS (Parkin Elmer DRC II) in National Geophysical Research Institute, Hyderabad, India. 


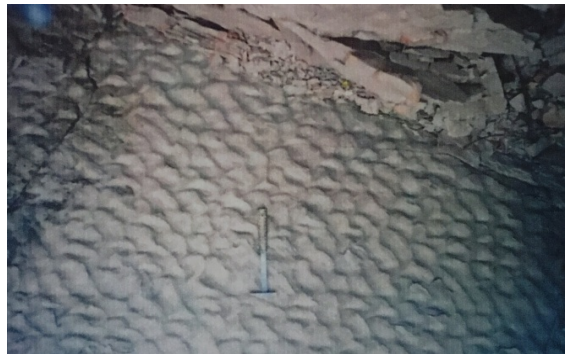

(a)

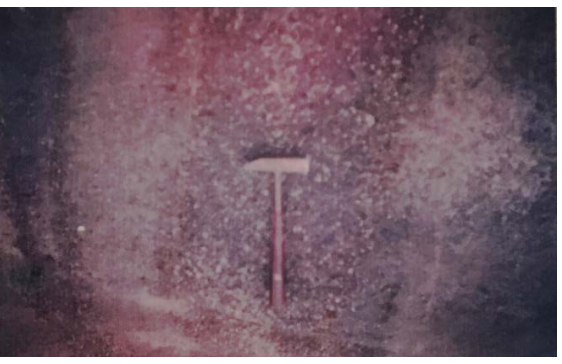

(b)

Plate 2. (a) Ripple marks of Tikak Parbat sandstones; (b) Gritty nature of Tipam sandstones (Lahkar, 2007).

\section{Petrographic Attributes of the Sandstones}

Detailed petrographic analyses and the data reflected in Table 2 and Table 3 to understand the volumetric abundance of different constituents are from samples used in geochemical analyses. Table 3 is derived out of Table 2 and it presents a comparative statement of dominant petrographic constituents of the Tikak Parbat sandstones and Tipam sandstones of Dilli area. Overall, both Tikak Parbat and Tipam sandstones are mainly quartzose arenite to sublitharenite types [15].

Quartz in both the sandstones comprise of monocrystalline (unit and undulose) and polycrystalline (composite, schistose and pressure) varieties, while the feldspars are plagioclase, microcline and orthoclase. Rock fragments of metamorphic, igneous and sedimentary origin as well as protomatrix and epimatrix are also seen. Cement is commonly calcareous, ferrugenous and siliceous. Muscovite, biotite and chlorite reflect the micaceous components. A few secondary cherts are observed along with the detrital ones (Plate 3).

Monocrystalline quartz indicates their descent from intrusive igneous rocks while the composite, schistose and pressure units reflect their derivation from a terrain hosting medium to high grade metamorphic and intrusive rocks. Petrographic association of monocrystalline quartz, plagioclase and potash feldspar along with mica suggest derivation of the sediments from an uplifted crystalline basement of granitic to granodioritic composition and extensive low to high grade metasedimentary terrains [16]. Both opaque and non-opaque varieties of heavy minerals are observed. Tourmaline, zircon, rutile, epidote, garnet, staurolite, kyanite, sillimanite and rare hornblende represent the non-opaques while iron oxide and ilmenite represent the opaques. Tectonic discrimination plots after Dickinson [2], Dickinson and Suczek [17] and Dickinson et al. [18] show the derivation of sediments from recycled orogen provenance. Climate plots after Suttner and Dutta [19] show concentration of plots mainly in the sub-humid to humid sector. Petrographic composition and heavy mineral suite of both the sandstone units along with the regional geological setting suggest their derivation from metamorphic, igneous and subordinate sedimentary source rocks transported mostly from Eastern Himalaya and Indo-Burma Range. 
Table 2. Modal analyses data of the Tikak Parbat sandstones and Tipam sandstones of Dilli area (Comp. = Composite; Pres. = Pressure; Schist. = Schistose; Feld. = Feldspar; Cem. = Cement; Acc. Min. = Accessory Minerals).

\begin{tabular}{|c|c|c|c|c|c|c|c|c|c|c|c|c|c|c|c|c|}
\hline \multicolumn{17}{|c|}{ TIKAK PARBAT SANDSTONES } \\
\hline \multirow{2}{*}{ SN } & \multirow{2}{*}{$\begin{array}{c}\text { Sample } \\
\text { No. }\end{array}$} & \multicolumn{4}{|c|}{ Monocrystalline Quartz } & \multicolumn{4}{|c|}{ Polycrystalline Quartz } & \multirow{2}{*}{$\begin{array}{c}\text { Total } \\
\text { Quartz }\end{array}$} & \multirow{2}{*}{ Feld. } & \multirow{2}{*}{$\begin{array}{l}\text { Rock } \\
\text { Frag. }\end{array}$} & \multirow{2}{*}{ Cem. } & \multirow{2}{*}{ Matrix } & \multirow{2}{*}{ Mica } & \multirow{2}{*}{$\begin{array}{l}\text { Acc } \\
\text { Min }\end{array}$} \\
\hline & & Unit & Undulose & Vein & QMT & Comp. & Pres. & Schist. & QPT & & & & & & & \\
\hline 1 & D9 & 16.66 & 25.12 & - & 41.78 & 11.28 & 7.17 & 14.1 & 32.55 & 74.37 & 1.53 & 7.17 & 8.71 & 5.12 & 2.3 & 0.76 \\
\hline 2 & D12 & 10.24 & 18.78 & - & 29.02 & 9.75 & 5.6 & 11.21 & 26.56 & 55.58 & 2.19 & 10.73 & 14.39 & 12.43 & 4.14 & 0.48 \\
\hline 3 & D16 & 16.04 & 22.55 & 1.39 & 39.98 & 7.9 & 6.51 & 14.65 & 29.06 & 69.04 & 1.39 & 8.6 & 10.69 & 7.9 & 2.09 & 0.23 \\
\hline 4 & D19 & 14.21 & 20.24 & - & 34.45 & 12.53 & 5.3 & 19.03 & 36.86 & 71.31 & 1.2 & 6.26 & 9.15 & 8.19 & 3.37 & 0.23 \\
\hline 5 & BP5 & 20.5 & 17.21 & 1.26 & 38.97 & 10.37 & 5.31 & 15.18 & 30.86 & 69.83 & 1.26 & 10.37 & 9.11 & 7.34 & 1.51 & 0.5 \\
\hline 6 & BP9 & 14.14 & 17.31 & - & 31.45 & 10.48 & 8.29 & 20.24 & 39.01 & 70.46 & 1.21 & 10.24 & 10 & 6.34 & 1.21 & 0.48 \\
\hline 7 & NB2 & 12.47 & 14.11 & 2.11 & 28.69 & 10.82 & 5.17 & 17.64 & 33.63 & 62.32 & 2.82 & 9.64 & 10.35 & 11.29 & 2.35 & 1.17 \\
\hline 8 & NB5 & 14.66 & 20.80 & - & 35.46 & 12.53 & 4.26 & 16.26 & 33.05 & 68.51 & 3.73 & 9.33 & 7.2 & 5.6 & 5.06 & 0.53 \\
\hline 9 & $\mathrm{~N} 4(1)$ & 14.87 & 16.41 & - & 31.28 & 10.76 & 4.1 & 16.15 & 31.01 & 62.29 & 1.79 & 11.53 & 12.30 & 8.2 & 3.58 & 0.25 \\
\hline 10 & N5(2) & 17.9 & 16.04 & 1.39 & 35.33 & 12.32 & 3.25 & 19.3 & 34.87 & 70.2 & 1.16 & 7.31 & 9.06 & 8.83 & 2.09 & 1.39 \\
\hline \multicolumn{17}{|c|}{ TIPAM SANDSTONES } \\
\hline \multirow{2}{*}{ SN } & Sample & \multicolumn{4}{|c|}{ Monocrystalline Quartz } & \multicolumn{4}{|c|}{ Polycrystalline Quartz } & Total & Feld & Rock & Som & Matri- & Micr & Acc. \\
\hline & No. & Unit & Undulose & Vein & QMT & Comp. & Pres. & Schist. & QPT & Quartz & Fela. & Frag. & Cem. & Matrix & Milca & Min. \\
\hline 1 & D25 & 10.54 & 10.81 & - & 21.35 & 18.37 & 2.43 & 12.16 & 32.96 & 54.31 & 8.64 & 10.54 & 14.32 & 7.29 & 4.32 & 0.54 \\
\hline 2 & D30 & 11.53 & 10.51 & - & 22.04 & 14.61 & 1.79 & 12.3 & 28.7 & 50.74 & 8.2 & 15.12 & 12.05 & 10.25 & 3.59 & - \\
\hline 3 & D34 & 12.47 & 10.11 & - & 22.58 & 12.7 & 1.17 & 14.58 & 28.45 & 51.03 & 7.52 & 10.11 & 15.05 & 9.17 & 5.41 & 1.64 \\
\hline 4 & D41 & 12.8 & 9.33 & 1.06 & 23.19 & 11.46 & 1.6 & 12.26 & 25.32 & 48.51 & 10.4 & 12.8 & 12.53 & 11.2 & 4 & 0.53 \\
\hline 5 & BP14 & 15.11 & 8.6 & 1.16 & 24.87 & 10.23 & 1.39 & 11.86 & 23.48 & 48.35 & 10 & 11.16 & 14.41 & 11.62 & 4.41 & - \\
\hline 6 & BP19 & 18.29 & 9.26 & 1.21 & 28.76 & 12.19 & 0.97 & 10.48 & 23.64 & 52.4 & 5.6 & 15.85 & 9.75 & 12.92 & 3.41 & - \\
\hline 7 & NB9 & 14.38 & 10.11 & 1.12 & 25.68 & 10.33 & O.89 & 10.56 & 21.78 & 47.39 & 9.43 & 10.33 & 14.6 & 12.8 & 4.26 & 1.34 \\
\hline 8 & NB14 & 17.9 & 10 & - & 27.9 & 10.46 & 1.39 & 10.69 & 22.54 & 50.44 & 8.83 & 12.55 & 9.06 & 14.41 & 3.72 & 0.69 \\
\hline 9 & B5 & 12.65 & 8.86 & 2.02 & 23.53 & 11.39 & 2.27 & 9.11 & 22.77 & 46.3 & 4.45 & 16.45 & 12.15 & 14.93 & 5.56 & - \\
\hline 10 & B12 & 18.29 & 9.75 & - & 28.04 & 15.6 & 1.21 & 8.53 & 25.34 & 53.38 & 8.29 & 10 & 15.36 & 9.51 & 3.41 & - \\
\hline
\end{tabular}

Table 3. Volumetric abundance range and comparative statement of dominant petrographic constituents of the Tikak Parbat sandstones and Tipam sandstones of Dilli area.

\begin{tabular}{ccc}
\hline Constituents (in \%) & Tikak Parbat sandstone & Tipam sandstone \\
\hline Quartz & 55.58 to 74.37 & 46.3 to 54.31 \\
Feldspar & 1.16 to 3.73 & 4.54 to 10.4 \\
Rock fragments & 7.17 to 11.53 & 10 to 16.45 \\
Matrix & 5.12 to 12.43 & 7.29 to 14.93 \\
Cement & 7.2 to 14.39 & 9.06 to 15.36 \\
Mica & 1.21 to 4.14 & 3.41 to 5.56 \\
\hline
\end{tabular}




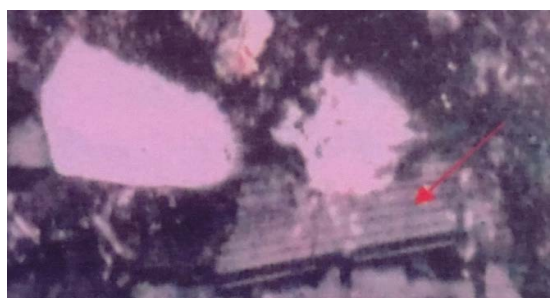

(a)

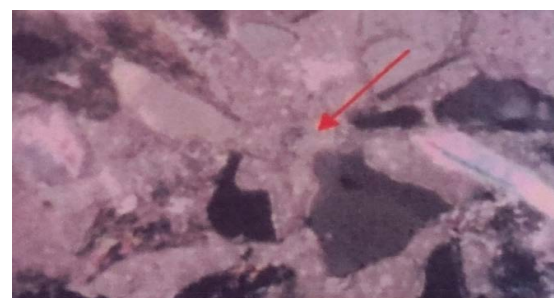

(b)

Plate 3. Photomicrograph (a) showing replacement of plagioclase by quartz in Tikak Parbat sandstones $(40 \times)$ and (b) showing calcareous cement in Tipam sandstones $(40 \times)$.

\section{Geochemistry Findings and Discussion}

\subsection{Major Oxides}

The abundance of major oxides and some commonly considered major oxide ratios of both Tikak Parbat sandstones and Tipam sandstones of the Dilli area are listed in Table 4 and Table 5 respectively. In terms of mean element abundance the values reflect the mineralogical character of the sandstones. Variations in major element geochemistry vide Harker diagrams were analysed in two groups1) in relation to $\mathrm{SiO}_{2}$ and, 2) variations between other radicals.

The Tikak Parbat sandstones have high $\mathrm{SiO}_{2}$ concentration of 63.69 to 92.75 wt $\%$ with an average of $83.38 \mathrm{wt} \%$, while the Tipam sandstones have moderate $\mathrm{SiO}_{2}$ concentration of 51.55 to $69.33 \mathrm{wt} \%$ with an average of $59.74 \mathrm{wt} \%$. It is interesting to note that $\mathrm{SiO}_{2}$ has an average abundance of $66 \%$ for sandstones derived from upper continental crust [20]. In the present case, the average $\mathrm{SiO}_{2}$ of Tikak Parbat sandstones is much higher at $83.38 \%$ while that of the Tipam sandstones, it is around $59.74 \%$ which means that sediment contributions were from deeper levels for the Tipam Sandstones.

In case of the Tikak Parbat sandstones, considering $\mathrm{SiO}_{2}$ as a common factor, it is seen that $\mathrm{Al}_{2} \mathrm{O}_{3}, \mathrm{Fe}_{2} \mathrm{O}_{3}, \mathrm{~K}_{2} \mathrm{O}, \mathrm{Na}_{2} \mathrm{O}, \mathrm{MnO}, \mathrm{CaO}, \mathrm{TiO}_{2}$ and $\mathrm{MgO}$ show negative correlation with it indicating free silica being sequestered in the form of quartz. However, Tipam sandstones correlations between $\mathrm{SiO}_{2}$ with $\mathrm{Al}_{2} \mathrm{O}_{3}, \mathrm{~K}_{2} \mathrm{O}$ and $\mathrm{Na}_{2} \mathrm{O}$ show positive relation while other radicals show a negative relation. There is a good amount of aluminosilicate represented by feldspars, mica and of course, the clays probably in case of the Tipam sandstones (Table 3).

The average $\mathrm{Al}_{2} \mathrm{O}_{3}$ content of Tikak Parbat sandstones is $7.16 \mathrm{wt} \%$, while it is $9.78 \mathrm{wt} \%$ for the Tipam sandstones. The presence of more matrix component in the Tipam sandstones than the Tikak Parbat sandstones supports the higher content of $\mathrm{Al}_{2} \mathrm{O}_{3}$ in the latter. It might be due to alteration of $\mathrm{K}$ feldspar. Correlation between alumina and oxides of $\mathrm{K}_{2} \mathrm{O}$ and $\mathrm{Fe}_{2} \mathrm{O}_{3}$ of both the sandstones shows negative nature suggesting their non association with phyllosilicates.

$\mathrm{K} 2 \mathrm{O} / \mathrm{Na}_{2} \mathrm{O}$ average ratios hovers around unity in Tipam sandstones and is attributed to the presence of nearly equivalent proportions of albitic plagioclase, $\mathrm{K}$-feldspar, mica and illite [21]. Proportion of $\mathrm{K}_{2} \mathrm{O}$ and $\mathrm{Na}_{2} \mathrm{O}$ in the Tikak Parbat sandstones is relatively less than the Tipam sandstones suggesting an environ- 
Table 4. Major oxides (in wt\%) and major oxide ratios of the Tikak Parbat sandstones of Dilli area.

\begin{tabular}{|c|c|c|c|c|c|c|c|c|c|c|c|}
\hline \multirow{2}{*}{$\begin{array}{l}\text { Major } \\
\text { Oxides }\end{array}$} & \multicolumn{11}{|c|}{ SAMPLE Nos. } \\
\hline & D9 & D12 & D16 & D19 & BP5 & BP9 & NB2 & NB5 & N4 (1) & N5 (2) & Avg. \\
\hline $\mathrm{SiO}_{2}$ & 91.63 & 63.69 & 87.15 & 89.52 & 86.7 & 85.7 & 74.62 & 92.75 & 76.05 & 86.06 & 83.38 \\
\hline $\mathrm{Al}_{2} \mathrm{O}_{3}$ & 5.03 & 15.05 & 6.08 & 4.55 & 5.18 & 5.13 & 12.07 & 3.56 & 11.75 & 3.23 & 7.16 \\
\hline $\mathrm{Fe}_{2} \mathrm{O}_{3}$ & 0.52 & 4.25 & 1.06 & 0.65 & 1.61 & 1 & 3.02 & 0.54 & 2.84 & 4.5 & 1.99 \\
\hline $\mathrm{CaO}$ & 0.04 & 2.78 & 0.23 & 0.14 & 0.15 & 0.21 & 0.28 & 0.02 & 0.29 & 0.26 & 0.44 \\
\hline $\mathrm{MgO}$ & 0.41 & 2.28 & 0.65 & 0.64 & 0.72 & 0.88 & 1.91 & 0.57 & 1.93 & 1.53 & 1.15 \\
\hline $\mathrm{K}_{2} \mathrm{O}$ & 0.53 & 1.16 & 0.92 & 0.6 & 0.72 & 0.66 & 1.36 & 0.45 & 1.54 & 0.41 & 0.83 \\
\hline $\mathrm{Na}_{2} \mathrm{O}$ & 0.52 & 1.72 & 0.32 & 0.26 & 0.31 & 0.28 & 2.09 & 0.25 & 2.35 & 0.18 & 0.82 \\
\hline $\mathrm{TiO}_{2}$ & 0.47 & 0.63 & 0.53 & 0.56 & 0.49 & 0.66 & 0.65 & 0.58 & 0.49 & 0.67 & 0.57 \\
\hline $\mathrm{MnO}$ & 0.016 & 0.083 & 0.02 & 0.022 & 0.027 & 0.024 & 0.048 & 0.019 & 0.042 & 0.08 & 0.038 \\
\hline $\mathrm{P}_{2} \mathrm{O}_{5}$ & 0.033 & 0.112 & 0.061 & 0.052 & 0.052 & 0.058 & 0.077 & 0.047 & 0.078 & 0.052 & 0.062 \\
\hline LOI & 1.41 & 7.41 & 1.77 & 1.7 & 1.96 & 1.85 & 3.64 & 1.72 & 3 & 3.85 & 2.83 \\
\hline Total & 100.6 & 99.16 & 98.8 & 98.7 & 97.92 & 96.45 & 99.76 & 100.5 & 100.36 & 100.82 & 99.31 \\
\hline CIA & 82.19 & 68.94 & 83.52 & 81.40 & 81.45 & 78.92 & 73.82 & 80.91 & 72.00 & 62.12 & 74.82 \\
\hline CIW & 89.98 & 76.98 & 91.70 & 91.92 & 91.84 & 91.28 & 83.59 & 92.95 & 81.65 & 88.01 & 85.04 \\
\hline PIW & 73.53 & 67.07 & 68.34 & 71.17 & 70.13 & 71.18 & 67.78 & 72.66 & 64.09 & 69.12 & 68.43 \\
\hline \multicolumn{12}{|l|}{ Major Oxide Ratio } \\
\hline $\mathrm{Fe}_{2} \mathrm{O}_{3}+\mathrm{MgO}$ & 0.93 & 6.53 & 1.71 & 1.29 & 2.33 & 1.88 & 4.93 & 1.11 & 4.77 & 6.03 & \\
\hline $\mathrm{Al}_{2} \mathrm{O}_{3} / \mathrm{SiO}_{2}$ & 0.05 & 0.23 & 0.06 & 0.05 & 0.05 & 0.05 & 0.16 & 0.03 & 0.15 & 0.03 & \\
\hline $\mathrm{K}_{2} \mathrm{O} / \mathrm{Na}_{2} \mathrm{O}$ & 1.01 & 0.67 & 2.87 & 2.3 & 2.32 & 2.35 & 0.65 & 1.8 & 0.65 & 2.27 & \\
\hline $\mathrm{Al}_{2} \mathrm{O}_{3} /\left(\mathrm{CaO}+\mathrm{Na}_{2} \mathrm{O}\right)$ & 8.98 & 3.34 & 11.05 & 11.37 & 5.95 & 4 & 2.36 & 4.5 & 2.26 & 0.69 & \\
\hline $\log \left(\mathrm{Na}_{2} \mathrm{O} / \mathrm{K}_{2} \mathrm{O}\right)$ & -0.0083 & 0.171 & -0.458 & -0.368 & -0.365 & 0.372 & 0.186 & -0.255 & 0.183 & -0.357 & \\
\hline $\log \left(\mathrm{Fe}_{2} \mathrm{O}_{3} / \mathrm{K}_{2} \mathrm{O}\right)$ & -0.0083 & 0.563 & 0.061 & 0.034 & 0.349 & 0.18 & 0.346 & 0.079 & 0.265 & 1.04 & \\
\hline $\log \left(\mathrm{SiO}_{2} / \mathrm{Al}_{2} \mathrm{O}_{3}\right)$ & 1.26 & 0.626 & 1.156 & 1.293 & 1.233 & 1.222 & 0.791 & 1.415 & 0.811 & 1.425 & \\
\hline $\mathrm{Al}_{2} \mathrm{O}_{3} / \mathrm{Na}_{2} \mathrm{O}$ & 9.67 & 8.75 & 19 & 17.5 & 16.7 & 18.32 & 5.77 & 14.24 & 5 & 17.94 & \\
\hline $\mathrm{TiO}_{2} / \mathrm{Al}_{2} \mathrm{O}_{3}$ & 0.09 & 0.04 & 0.08 & 0.12 & 0.09 & 0.12 & 0.05 & 0.16 & 0.04 & 0.02 & \\
\hline $\mathrm{MnO} / \mathrm{Fe}_{2} \mathrm{O}_{3}$ & 0.03 & 0.01 & 0.01 & 0.03 & 0.01 & 0.02 & 0.01 & 0.03 & 0.01 & 0.01 & \\
\hline $\mathrm{Al}_{2} \mathrm{O}_{3}+\mathrm{K}_{2} \mathrm{O}+\mathrm{Na}_{2} \mathrm{O}$ & 6.08 & 17.93 & 7.32 & 5.41 & 6.21 & 6.07 & 15.52 & 4.26 & 15.64 & 3.82 & \\
\hline $\mathrm{SiO}_{2} / \mathrm{Al}_{2} \mathrm{O}_{3}$ & 18.21 & 4.23 & 14.33 & 19.67 & 16.73 & 16.7 & 6.18 & 26.05 & 6.47 & 26.64 & \\
\hline
\end{tabular}

Table 5. Major oxides (in wt\%) and major oxide ratios of the Tipam sandstones of Dilli area.

\begin{tabular}{|c|c|c|c|c|c|c|c|c|c|c|c|}
\hline \multirow{2}{*}{$\begin{array}{l}\text { Major } \\
\text { Oxides }\end{array}$} & \multicolumn{11}{|c|}{ SAMPLE Nos. } \\
\hline & D25 & D30 & D34 & $\mathrm{D} 41$ & BP14 & BP19 & NB9 & NB14 & B5 & B12 & Avg. \\
\hline $\mathrm{SiO}_{2}$ & 54.14 & 65.47 & 52.49 & 63.54 & 62.24 & 69.33 & 59.81 & 57.43 & 51.55 & 61.39 & 59.74 \\
\hline $\mathrm{Al}_{2} \mathrm{O}_{3}$ & 9.02 & 13.58 & 8.38 & 9.35 & 9.14 & 12.41 & 8 & 8.4 & 9.57 & 9.99 & 9.78 \\
\hline $\mathrm{Fe}_{2} \mathrm{O}_{3}$ & 2.36 & 5.98 & 2.18 & 3.84 & 2.44 & 3.97 & 2.95 & 2.1 & 2.77 & 4.15 & 3.27 \\
\hline $\mathrm{CaO}$ & 16.16 & 1.33 & 16.29 & 8.39 & 8.61 & 0.86 & 12.23 & 14.66 & 17.01 & 4.21 & 9.97 \\
\hline
\end{tabular}




\section{Continued}

\begin{tabular}{|c|c|c|c|c|c|c|c|c|c|c|c|}
\hline $\mathrm{MgO}$ & 2.02 & 3.96 & 1.92 & 2.37 & 2.8 & 3.08 & 2.56 & 1.79 & 2.23 & 3.55 & 2.02 \\
\hline $\mathrm{K}_{2} \mathrm{O}$ & 1.67 & 1.89 & 1.56 & 1.63 & 1.8 & 2.1 & 1.71 & 1.63 & 1.65 & 1.73 & 1.74 \\
\hline $\mathrm{Na}_{2} \mathrm{O}$ & 1.29 & 2.04 & 1.23 & 1.45 & 2.01 & 2.07 & 1.61 & 1.46 & 1.2 & 1.62 & 1.75 \\
\hline $\mathrm{TiO}_{2}$ & 0.38 & 0.69 & 0.38 & 0.62 & 0.25 & 0.54 & 0.36 & 0.34 & 0.38 & 0.71 & 0.46 \\
\hline $\mathrm{MnO}$ & 0.601 & 0.069 & 0.699 & 0.24 & 0.518 & 0.059 & 0.494 & 0.663 & 0.61 & 0.153 & 0.41 \\
\hline $\mathrm{P}_{2} \mathrm{O}_{5}$ & 0.15 & 0.144 & 0.137 & 0.105 & 0.088 & 0.234 & 0.074 & 0.121 & 0.16 & 0.181 & 0.139 \\
\hline LOI & 11.9 & 4.02 & 13.09 & 6.82 & 8.17 & 3.52 & 8.56 & 12.49 & 11.74 & 14.53 & 9.48 \\
\hline Total & 99.69 & 99.17 & 98.36 & 98.35 & 98.07 & 98.18 & 98.36 & 101.08 & 98.87 & 102.21 & 99.23 \\
\hline CIA & 32.05 & 72.08 & 30.52 & 44.91 & 42.39 & 71.16 & 33.97 & 32.12 & 32.52 & 56.92 & 42.08 \\
\hline CIW & 34.08 & 80.12 & 32.36 & 48.72 & 46.26 & 80.90 & 36.63 & 34.26 & 34.45 & 63.15 & 45.49 \\
\hline PIW & 26.12 & 62.05 & 24.84 & 37.08 & 34.04 & 59.12 & 26.71 & 25.89 & 26.91 & 47.07 & 34.60 \\
\hline \multicolumn{12}{|l|}{ Major Oxide Ratio } \\
\hline $\mathrm{Fe}_{2} \mathrm{O}_{3}+\mathrm{MgO}$ & 4.38 & 9.94 & 4.1 & 6.21 & 5.24 & 7.05 & 5.51 & 3.89 & 5 & 7.7 & \\
\hline $\mathrm{Al}_{2} \mathrm{O}_{3} / \mathrm{SiO}_{2}$ & 0.16 & 0.2 & 0.15 & 0.14 & 0.14 & 0.17 & 0.13 & 0.14 & 0.18 & 0.16 & \\
\hline $\mathrm{K}_{2} \mathrm{O} / \mathrm{Na}_{2} \mathrm{O}$ & 1.29 & 0.92 & 1.26 & 1.12 & 0.89 & 1.01 & 1.06 & 0.11 & 1.37 & 1.06 & \\
\hline $\mathrm{Al}_{2} \mathrm{O}_{3} /\left(\mathrm{CaO}+\mathrm{Na}_{2} \mathrm{O}\right)$ & 0.51 & 4.02 & 0.47 & 0.95 & 0.86 & 4.23 & 0.57 & 0.52 & 0.52 & 1.71 & \\
\hline $\log \left(\mathrm{Na}_{2} \mathrm{O} / \mathrm{K}_{2} \mathrm{O}\right)$ & -0.112 & 0.033 & -0.103 & -0.05 & 0.047 & -0.0063 & -0.026 & -0.047 & -0.138 & -0.028 & \\
\hline $\log \left(\mathrm{Fe}_{2} \mathrm{O}_{3} / \mathrm{K}_{2} \mathrm{O}\right)$ & 0.15 & 0.5 & 0.145 & 0.372 & 0.132 & 0.276 & 0.236 & 0.11 & 0.224 & 0.38 & \\
\hline $\log \left(\mathrm{SiO}_{2} / \mathrm{Al}_{2} \mathrm{O}_{3}\right)$ & 0.778 & 0.683 & 0.769 & 0.832 & 0.833 & 0.747 & 0.873 & 0.834 & 0.731 & 0.788 & \\
\hline $\mathrm{Al}_{2} \mathrm{O}_{3} / \mathrm{Na}_{2} \mathrm{O}$ & 6.99 & 6.65 & 6.81 & 6.44 & 4.54 & 5.99 & 4.96 & 5.75 & 7.97 & 6.16 & \\
\hline $\mathrm{TiO}_{2} / \mathrm{Al}_{2} \mathrm{O}_{3}$ & 0.04 & 0.05 & 0.04 & 0.06 & 0.02 & 0.04 & 0.04 & 0.04 & 0.03 & 0.07 & \\
\hline $\mathrm{MnO} / \mathrm{Fe}_{2} \mathrm{O}_{3}$ & 0.25 & 0.01 & 0.32 & 0.06 & 0.21 & 0.01 & 0.16 & 0.31 & 0.22 & 0.03 & \\
\hline $\mathrm{Al}_{2} \mathrm{O}_{3}+\mathrm{K}_{2} \mathrm{O}+\mathrm{Na}_{2} \mathrm{O}$ & 11.98 & 17.51 & 11.17 & 12.43 & 12.95 & 16.58 & 11.32 & 11.49 & 12.42 & 13.34 & \\
\hline $\mathrm{SiO}_{2} / \mathrm{Al}_{2} \mathrm{O}_{3}$ & 6 & 4.82 & 6.26 & 6.79 & 6.8 & 5.58 & 7.47 & 6.83 & 5.38 & 6.14 & \\
\hline
\end{tabular}

ment detrimental for survival of feldspars. The age factor is also responsible for this compositional status. The low values of $\mathrm{K}_{2} \mathrm{O} / \mathrm{Al}_{2} \mathrm{O}_{3}$ ( 0.116 for Tikak Parbat and 0.178 for Tipam sandstones) probably suggest sedimentary recycling or increase in the degree of source area weathering.

Titanite $\left(\mathrm{TiO}_{2}\right)$ is persistently low in abundance. $\mathrm{TiO}_{2}$ concentration is found to occur between 0.47 to $0.67 \mathrm{wt} \%$ for Tikak Parbat sandstones and 0.25 to 0.71 $\mathrm{wt} \%$ for the Tipam sandstones. Titanium is characteristic of sediments that have undergone long period of consistent sub-aerial weathering. It is a stable mineral phase and might have come from metamorphosed argillaceous rocks or acid igneous rocks as detrital rutile or, from pre-existing sedimentary rocks and acid igneous rocks as detrital ilmenite rather than a soluble fraction. It is indicative of continental geochemical setting and, its content decreases with increasing distance from land [22].

The low average value of $\mathrm{Al}_{2} \mathrm{O}_{3} / \mathrm{SiO}_{2}$ for the sandstones $(0.03-0.16$ for the Ti- 
kak Parbat and $0.13-0.18$ for the Tipam sandstones) is also a hint of quartz enrichment [23]. Contrary to that is the ratio of $\mathrm{SiO}_{2} / \mathrm{Al}_{2} \mathrm{O}_{3}$ for sandstones (4.23 - 26.05 for the Tikak Parbat and 4.82 - 7.47 for the Tipam Sandstones). Our analyses suggest the chemical maturity of the sandstones of Tikak Parbat Formation as relatively higher and it is also reflected by the $\mathrm{TiO}_{2} / \mathrm{Al}_{2} \mathrm{O}_{3}$ ratio [24] and $\mathrm{SiO}_{2} / \mathrm{Al}_{2} \mathrm{O}_{3}+\mathrm{K}_{2} \mathrm{O}+\mathrm{Na}_{2} \mathrm{O}$ plot (Figure 2) of Suttner and Dutta [19]. While Tikak Parbat Sandstones reflect the influence of both arid and humid climatic conditions, Tipam sandstones seem to have been deposited under arid conditions.

\subsection{Palaeoweathering}

Alteration of minerals due to chemical weathering mainly depends on the mineral chemistry, intensity and the duration of weathering as well as climate. One of the dominant processes during weathering in the upper crust is the degradation of feldspars and formation of clay minerals. The degradation of feldspar, which is very sensitive to chemical weathering, increases the mobility of many elements like $\mathrm{K}, \mathrm{Na}, \mathrm{Ca}$ [20] [25] only to reside in the clay minerals and soil profile. Alteration of rocks during weathering results in depletion of alkalis and alkaline earth elements and preferential enrichment of $\mathrm{Al}_{2} \mathrm{O}_{3}$, [26]. The amount of these chemical elements surviving in the soil profiles and in the sediments derived from them is a sensitive index of the intensity of weathering [27]. The influence of weathering on sedimentary rocks can be calculated by using Chemical Index of Alteration (CIA) value [28]. The CIA value which indicates the degree of weathering of source rocks is determined by the equation:

$$
\mathrm{CIA}=\left[\mathrm{Al}_{2} \mathrm{O}_{3} /\left(\mathrm{Al}_{2} \mathrm{O}_{3}+\mathrm{CaO} \text { sil. }+\mathrm{Na}_{2} \mathrm{O}+\mathrm{K}_{2} \mathrm{O}\right)\right] \times 100
$$

The CIA gives a measure of the ratio of original/primary minerals and

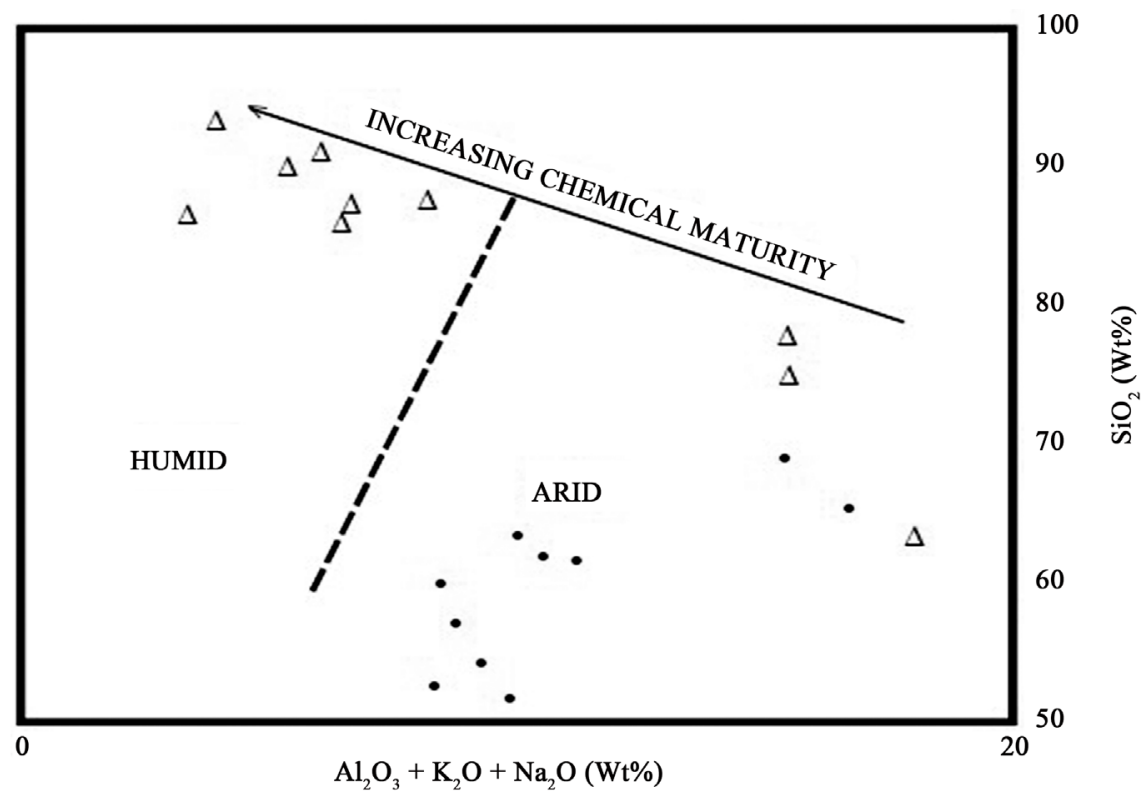

Figure 2. Scatter plot of $\mathrm{Al}_{2} \mathrm{O}_{3}+\mathrm{K}_{2} \mathrm{O}+\mathrm{Na}_{2} \mathrm{O}$ vs. $\mathrm{SiO}_{2}$ of Tikak Parbat sandstones $(\Delta)$ and Tipam sandstones $(\bullet)$, after Suttner and Dutta, 1986. 
secondary products such as clay minerals. CIA values ranges from almost 50 in case of fresh rocks to 100 for completely weathered rocks, consisting entirely of secondary minerals. High CIA and PIA values $(75-100)$ indicate intensive weathering in the source area whereas low values $(\leq 60)$ indicate low weathering in the source area. The CIA is a good measure of palaeoweathering conditions and it essentially monitors the progressive weathering of feldspars to clay minerals [7]. The present study shows that K-feldspar is less in Tikak Parbat sandstones compared to Tipam sandstones. Hence CIA value of Tikak Parbat sandstones is high (62.12 to 83.52; ave.: 74.82) indicating high intensity of chemical weathering in the source areas and lower CIA value (32.52 to 72.08; ave.: 42.08 ) of Tipam sandstones is an indication of low rate of chemical weathering in the source areas.

Apart from the Chemical Index of Alteration (CIA), Chemical Index of Weathering (CIW) put forward by Harnois [29] and Plagioclase Index of Alteration (PIA) proposed by Fedo et al. [30] are also good reflectors of the extent of weathering at source. PIA and CIA can be worked out by the following equations:

$$
\begin{gathered}
\mathrm{CIW}=100\left[\mathrm{Al}_{2} \mathrm{O}_{3} /\left(\mathrm{Al}_{2} \mathrm{O}_{3}+\mathrm{CaO}+\mathrm{Na}_{2} \mathrm{O}\right)\right] \\
\mathrm{PIA}=100\left[\left(\mathrm{Al}_{2} \mathrm{O}_{3}-\mathrm{K}_{2} \mathrm{O}\right) /\left(\mathrm{Al}_{2} \mathrm{O}_{3}+\mathrm{CaO}+\mathrm{Na}_{2} \mathrm{O}-\mathrm{K}_{2} \mathrm{O}\right)\right]
\end{gathered}
$$

The CIW concept is similar to CIA except that it eliminates $\mathrm{K}_{2} \mathrm{O}$ from the equation. CIW does not account for $\mathrm{Al}_{2} \mathrm{O}_{3}$ associated with $\mathrm{K}$-feldspar. PIA on the other hand may be used as an alternative to CIW as because plagioclase is abundant in silicate rocks and dissolves rapidly. PIA is generally used when plagioclase weathering needs to be monitored.

CIW and PIA patterns in the present case are seen to support the CIA trend. CIW value of Tikak Parbat sandstone varies from $76.98 \%$ to $92.95 \%$ (ave.: 85.04\%) while the same for Tipam sandstones range from $32.36 \%$ to $80.90 \%$ (ave.: 45.49\%). Similarly, PIA value of Tikak Parbat sandstone varies from 64.09\% to $73.53 \%$ (ave.: $68.43 \%$ ) while the same for Tipam sandstones vary from $24.84 \%$ to $62.05 \%$ (ave.: $34.6 \%$ ). CIA, PIA and CIW values greater than $60 \%$ as shown by Tikak Parbat sandstones indicate moderate to high weathering either at the source or during transport before deposition [30].

\subsection{Provenance}

Source rock composition is commonly thought to be the dominant factor that controls the composition of sediments [20]. Secondary processes like weathering and diagenesis can also variably impact the chemical composition [31] and as such, one can best rely on elements that show little mobility under geologic conditions. However, composition of clastic rocks like sandstone and shale is also influenced by the nature of sedimentary processes within the depositional basin, the kind of dispersal paths that link provenance to the basin and plate tectonics [17].

Condie [32] proposed a ternary diagram of $\mathrm{Fe}_{2} \mathrm{O}_{3}-\mathrm{MgO}-\mathrm{TiO}_{2}$ for determina- 
tion of the source rock of the sediments which in the present case reflects a granite-granodiorite-quartz monzonite provenance for the Tikak Parbat sandstones and granite-granodiorite provenance for the Tipam sandstones (Figure 3). The $\mathrm{CaO}-\mathrm{Na}_{2} \mathrm{O}-\mathrm{K}_{2} \mathrm{O}$ ternary diagram plots after Le Maitre [33] largely shows a granitic provenance for the Tikak Parbat sandstones and andesitic to granitic sources for the Tipam sandstones (Figure 4).

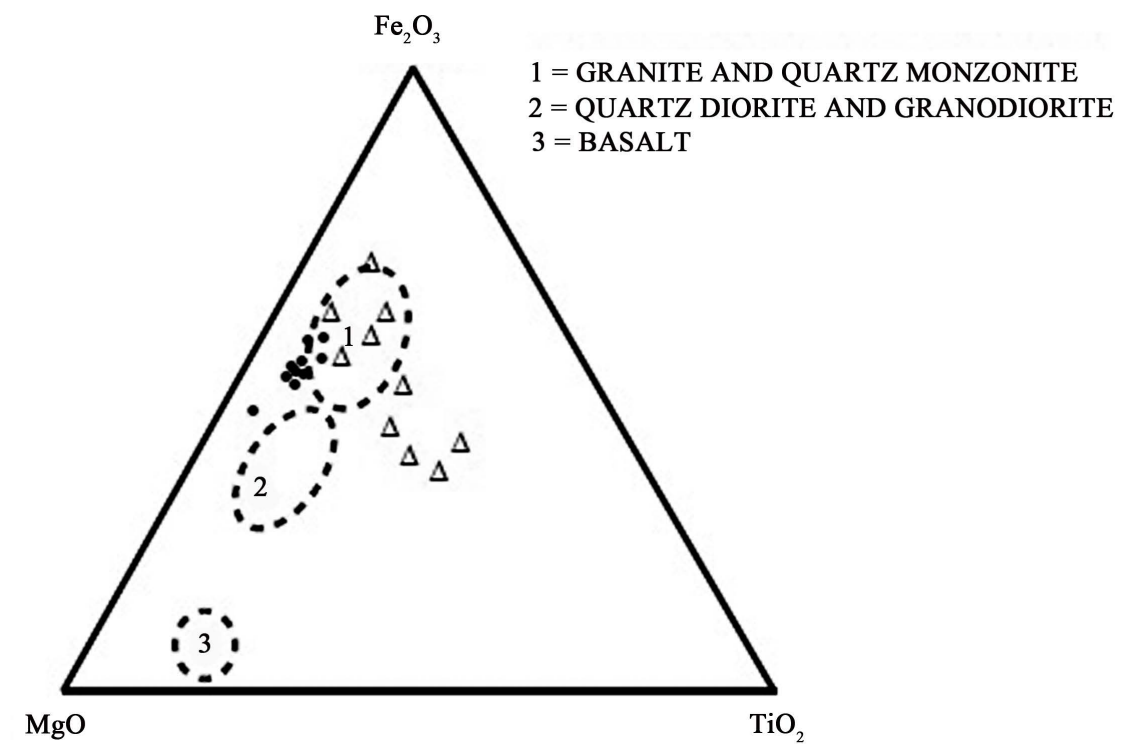

Figure 3. $\mathrm{Fe}_{2} \mathrm{O}_{3}-\mathrm{TiO}_{2}-\mathrm{MgO}$ composition diagram showing compositional range of the Tikak Parbat sandstones $(\Delta)$ and Tipam sandstones $(\bullet)$ and common igneous rocks (cf. Condie, 1967).

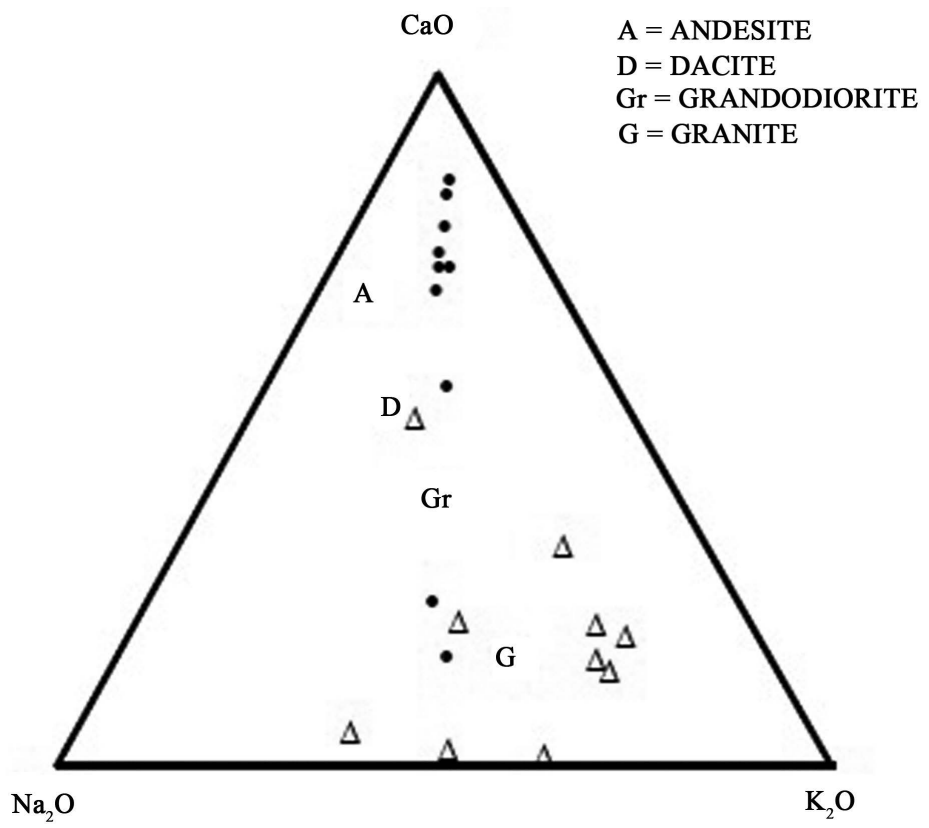

Figure 4. $\mathrm{CaO}-\mathrm{Na}_{2} \mathrm{O}-\mathrm{K}_{2} \mathrm{O}$ plot of Tikak Parbat sandstones $(\Delta)$ and Tipam sandstones $(\bullet)$, (cf. Bhatia, 1983), (Also shown are the average of Andesite (A), Dacite (D), Grandodiorite (Gr), Granite (G) (after LeMaitre, 1976). 
Association of Tipam sandstone unconformably overlying Barail Group of rocks has been encountered in the Noa Dihing upstream of Miao in Arunachal Pradesh [34]. The same association has also been encountered in Upper Brahmaputra plains in Upper Assam [35]. The presence of coniferous pollen Podocarpidites in the Tipam sandstones also point towards a Himalayan source for the sediments which is also indicated by the heavy mineral assemblage [36]. Abor Volcanic Formation which is considered coeval with lower Permian Panjal Volcanic Formation of N.W. Himalayas describes mafic volcanic constituents of Eastern Himalayas in Arunachal Pradesh. Studies of Talukdar and Mazumdar [37] shows Abor Volcanic suite to comprise of basalt, andesite, acidic tuffs, lapillis and agglomerates. Reflectance of granodioritic and andesitic provenance in some provenance analyses may be due to contribution of clasts from the Abor Volcanics as well as granodiorites of Lohit Complex [38]. On a regional scale these sediments have been derived from metamorphic, igneous and subordinate sedimentary rocks transported mainly from the Eastern Himalayas and the Indo-Burman Ranges during Oligocene to Miocene time [39]. While Tikak Parbat sandstones were deposited under deltaic to near shore framework, Tipam sandstones were laid down under fluviatile regime [40].

\subsection{Tectonic Setting}

Plate tectonic settings of provenance and depositional basins leave huge impressions on various attributes of siliciclastic sedimentary rocks. Bhatia [23] and Roser and Korsch [6] used composition as a tool to decipher the tectonic setting of sediment accumulation. However, to infer tectonic setting of provenance of ancient siliciclastic sedimentary rocks, several major-trace-rare earth element based discrimination diagrams have been proposed. According to McLennan et al. [41] the tectonic setting discrimination diagrams can provide reliable results for siliciclastic rocks that have not been strongly affected by post-depositional weathering/metasomatism/metamorphism. In the present case, tectonic setting discrimination, plots suggested by Blatt et al. [1], Bhatia [23] and Roser and Korsch [6] were used.

Bhatia [23] recognized four types of settings namely Oceanic Island Arc (OIA), Continental Island Arc (CIA), Active Continental Margin (ACM) and Passive Margin (PM). The parameters that Bhatia considered to unearth the tectonic setup of deposition were mainly based on major oxide ratios comprising of elements of maximum and minimum mobility and, crustal and oceanic affinity. The plots in the binary diagrams for Tikak Parbat sandstones are close to ACM and PM Fields while those of Tipam sandstones are mostly close to CIA and ACM (Figures 5(a)-(d)). In the binary discrimination diagram of Roser and Korsch [6] the Tikak Parbat Sandstones plots mostly in the PM while Tipam Sandstones, plots are mainly seen falling in ACM field (Figure 6). Sandstones of PM type are derived from stable continental areas while those of ACM type are derived from uplifted areas [6]. Rifted continental margin, intracratonic and rift 


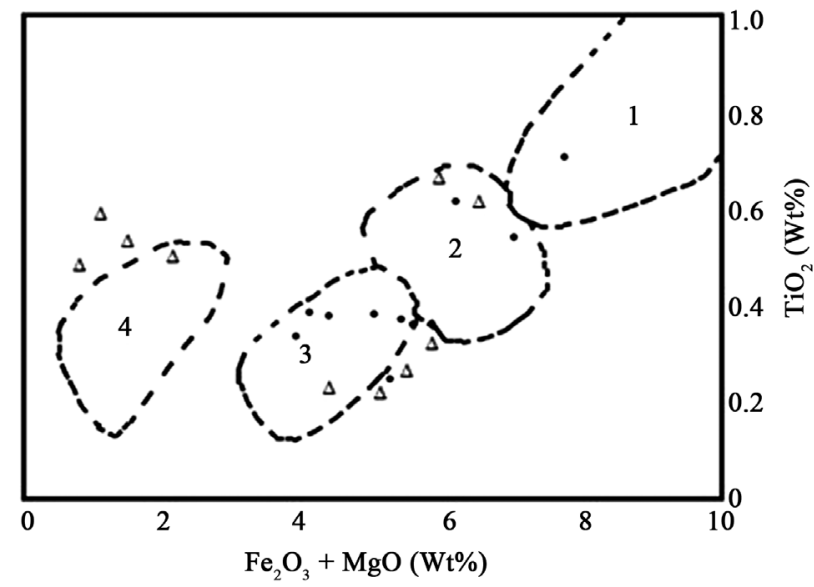

(a)

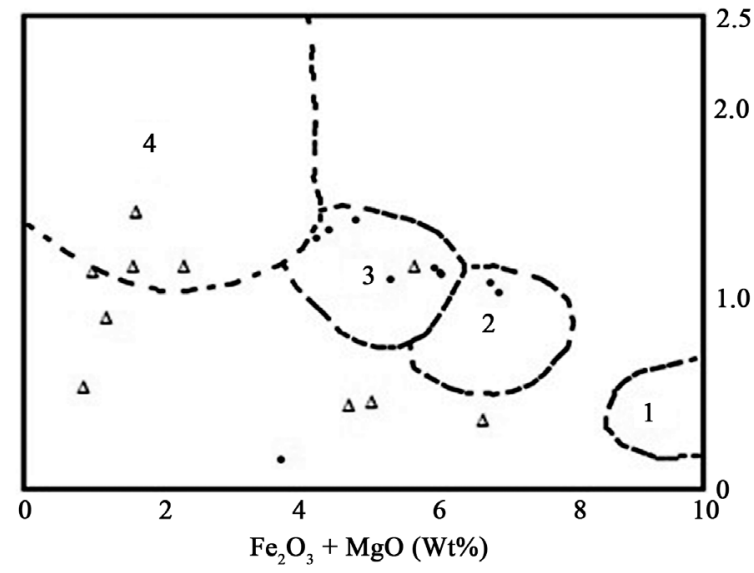

(c)

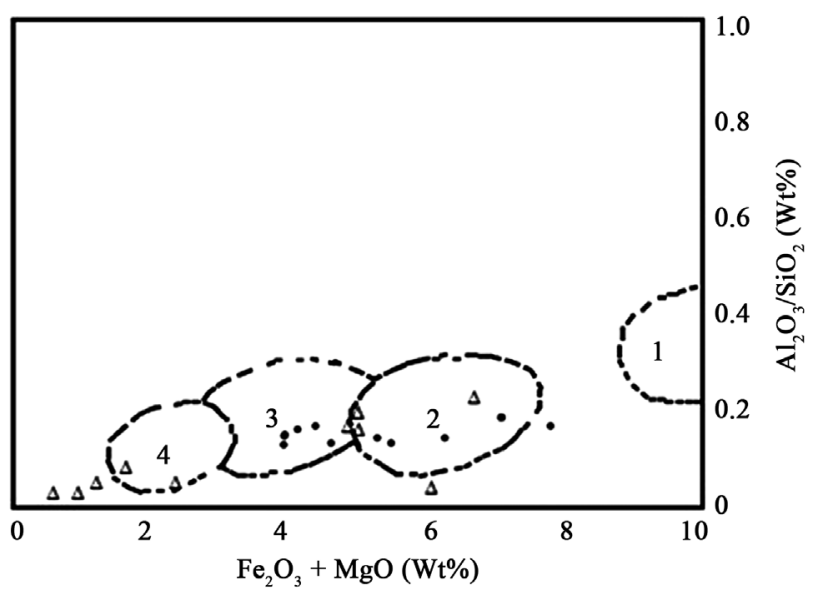

(b)

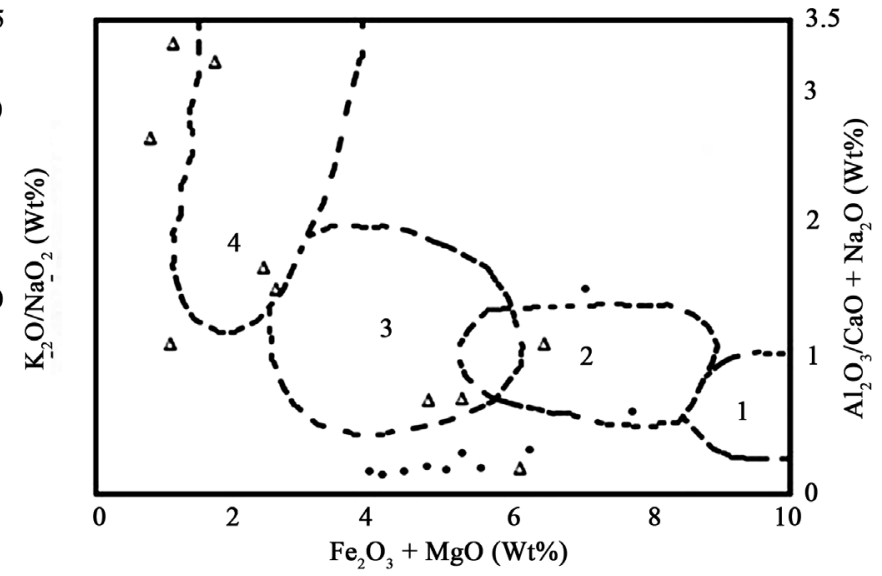

(d)

Figure 5. Scatter plot of: (a) $\mathrm{Fe}_{2} \mathrm{O}_{3}+\mathrm{MgO}$ vs. $\mathrm{TiO}_{2}$; (b) $\mathrm{Fe}_{2} \mathrm{O}_{3}+\mathrm{MgO}$ vs. $\mathrm{Al}_{2} \mathrm{O}_{3}+\mathrm{SiO}_{2}$; (c) $\mathrm{Fe}_{2} \mathrm{O}_{3}+\mathrm{MgO}$ vs. $\mathrm{K}_{2} \mathrm{O}+\mathrm{Na}_{2} \mathrm{O}$, and (d) $\mathrm{Fe}_{2} \mathrm{O}_{3}+\mathrm{MgO}$ vs. $\mathrm{Al}_{2} \mathrm{O}_{3} / \mathrm{CaO}+\mathrm{Na}_{2} \mathrm{O}$ of Tikak Parbat sandstones $(\Delta)$ and Tipam sandstones $(\bullet) .(1=$ Field of Oceanic Island Arc, 2 = Continental Island Arc, 3 = Active Continental Margin, 4 = Passive Margin, cf., Bhatia 1983).

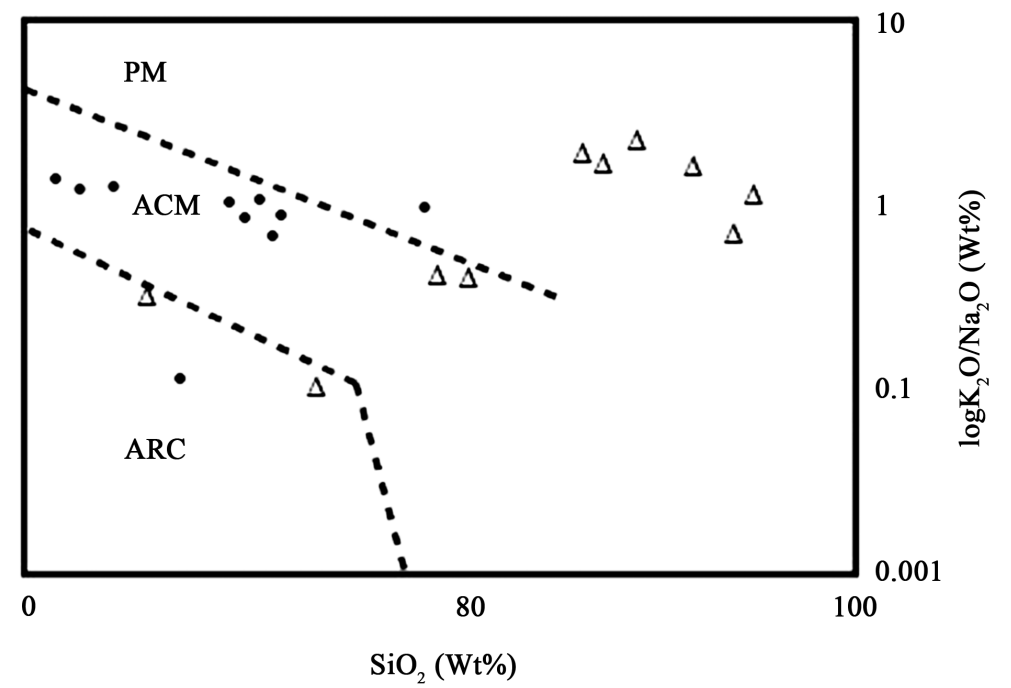

Figure 6. Satter plot of $\mathrm{SiO}_{2}$ vs. $\log \left(\mathrm{K}_{2} \mathrm{O} / \mathrm{Na}_{2} \mathrm{O}\right)$ of Tikak Parbat sandstones $(\Delta)$ and $\mathrm{Ti}$ pam sandstones $(\bullet)$ (after Roser and Korsch, 1986). 
bounded basins are generally reflected by unstable mineralogy. Tectono-province plots based on petrographic investigations of the present sandstones point towards their derivation form a recycled provenance [15]. Low $\mathrm{Al}_{2} \mathrm{O}_{3} / \mathrm{SiO}_{2}$ ratio of sandstones is further characteristic of quartz source deposited in a Passive Continental Margin Setting [42]. However, overlapping plots between passive and active continental margin settings reflect a complex provenance and history of recycling of these sediments [23].

\subsection{Geochemical Classification of Sandstones}

Geochemical classification of terrigenous sedimentary rocks has been proposed by many authors based on major element composition [1] [43] [44]. Using the indices of $\mathrm{SiO}_{2} / \mathrm{Al}_{2} \mathrm{O}_{3}$ and $\mathrm{Na}_{2} \mathrm{O} / \mathrm{K}_{2} \mathrm{O}$ ratios Pettijohn et al. (1972) in Herron [44] proposed a classification for terrigenous sands based on a plot of $\log \left(\mathrm{Na}_{2} \mathrm{O} /\right.$ $\left.\mathrm{K}_{2} \mathrm{O}\right)$ versus $\log \left(\mathrm{SiO}_{2} / \mathrm{Al}_{2} \mathrm{O}_{3}\right)$. Herron [44] modified the diagram of Pettijohn et al. (1972) using $\log \left(\mathrm{Fe}_{2} \mathrm{O}_{3} / \mathrm{K}_{2} \mathrm{O}\right)$ instead of $\left(\mathrm{Na}_{2} \mathrm{O} / \mathrm{K}_{2} \mathrm{O}\right)$.

The plots after Herron [44] for Tikak Parbat sandstones fall mostly in "sublitharenite" to "wacke" field. The plots for Tipam sandstones fall mostly within "wacke" field (Figure 7). However, petrographically both the sandstones have been identified as quartzose arenite and sublitharenite types. This difference in petrographic and geochemical nomenclature arises from the fact that finer populations are ignored in modal analyses petrographically. These finer fragments are an integral part in whole rock analyses and they contribute $\mathrm{Al}_{2} \mathrm{O}_{3}$. This shifts the distribution mostly to "sublitharenite" and "wacke" field.

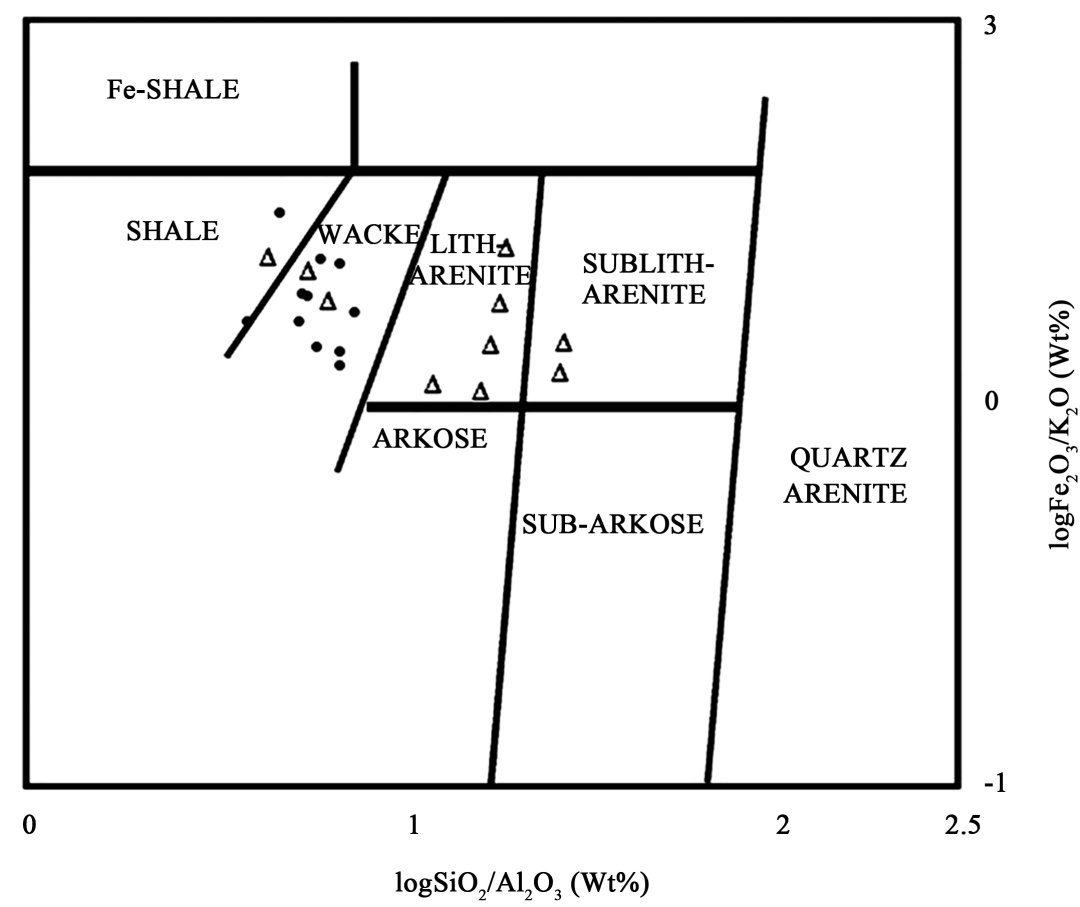

Figure 7. Geochemical classification for terrigenous sands (after Herron, 1988) of the Tikak Parbat sandstones $(\Delta)$ and Tipam sandstones $(\bullet)$. 


\subsection{Trace Elements}

A few trace elements and trace elemental ratios help ascertain geochemical attributes of sandstones. Trace element concentrations in sediments result from the competing influences of the provenance, weathering, diagenesis, sediment sorting and the aqueous geochemistry of the individual elements. These may also be controlled by the concentration of heavy minerals. As such, trace element geochemistry facilitate in distinguishing source rock composition and depositional environment [43] [45]. They can also be used to deduce the palaeotectonic setting of sedimentary packages [5] [46]. Low mobility of the trace elements during sedimentary processes and their low residence time in sea water makes them suitable for provenance and tectonic setting determinations of clastic sediments. These elements are in fact transported quantitatively into clastic sediments or sedimentary rocks during weathering and transportation and as such they carry the impressions of parent materials [5] [47].

Distribution of the trace elements for the Tikak Parbat sandstones (Table 6) and Tipam sandstones (Table 7) does not show much difference from the UCC [48]. There are some exceptions too. Copper and Zirconium are less in abundance relative to UCC. The presence of each trace element suggests some background information about the sandstone. For example, sufficient amount of Co, $\mathrm{Cr}$ and $\mathrm{Ni}$ in the sandstones suggests that these elements were derived from ferromagnesian minerals of metamorphic rocks. Geochemical analyses of Abor volcanic [49] and serpentinites of Tidding Formation of Lohit Complex [50] of the Eastern Himalayas which are presumed to be source $\operatorname{rock}(\mathrm{s})$ also report the presence of elements like $\mathrm{Cr}$, $\mathrm{Co}$ and $\mathrm{Ni}$. Similarly $\mathrm{Pb}$ is also derived from source rocks which contributed Fe to the sediments.

The $\mathrm{Ba}: \mathrm{Al}_{2} \mathrm{O}_{3}$ relationship of Tikak Parbat sandstones is strongly positive $\left(\mathrm{R}^{2}\right.$ $=0.700)$ and the same for Tipam sandstones is weakly positive $\left(R^{2}=0.402\right)$. Similarly, the $\mathrm{Rb}: \mathrm{Al}_{2} \mathrm{O}_{3}$ relationship of Tikak Parbat sandstones is strongly positive $\left(\mathrm{R}^{2}=0.860\right)$ and the same for Tipam sandstones is of lower much value $\left(\mathrm{R}^{2}=\right.$ 0.229) compared to Tikak Parbat sandstones. These correlations suggest that phyllosilicate minerals have more distinct control on the distribution of $\mathrm{Ba}$ and $\mathrm{Rb}$ in case of the Tikak Parbat sandstones compared to the Tipams. A similar finding comes out in case of the relationship $\mathrm{Ba}: \mathrm{K}_{2} \mathrm{O}$ which is otherwise positive. In case of Tikak Parbat sandstones $\mathrm{R}^{2}$ is 0.961 while it is 0.058 in case of the Tipams. Feldspar is a major host of $\mathrm{Ba}$ and $\mathrm{Rb}$ in terrigenous sedimentary rocks. Feldspars and Illites had more control in the distribution of Ba in Tikak Parbat sandstones. Analogous findings have come up from the ration $\mathrm{Ti}: \mathrm{Nb}$ as well.

The $\mathrm{Sr}: \mathrm{Al}_{2} \mathrm{O}_{3}$ relationship is positive in Tikak Parbat sandstones $\left(\mathrm{R}^{2}=0.59\right)$ while it is negative in Tipam sandstones $\left(R^{2}=-0.509\right)$. The Sr content of sedimentary rocks is variable because of many influences on $\mathrm{Sr}$ in low temperature depositional environments [51]. Sr for example can be affected by the presence of Ca. Additional Sr can be incorporated in diagenetic carbonate, and fractionation of $\mathrm{Sr}$ can result from the weathering of feldspars, particularly plagioclase. In 
Table 6. Trace element concentration (in ppm) and some trace element ratios of the Tikak Parbat sandstones of Dilli area.

\begin{tabular}{|c|c|c|c|c|c|c|c|c|c|c|}
\hline \multirow{2}{*}{$\begin{array}{c}\text { Trace } \\
\text { elements }\end{array}$} & \multicolumn{10}{|c|}{ SAMPLE Nos. } \\
\hline & D9 & D12 & D16 & D19 & BP5 & BP9 & NB2 & NB5 & N4(1) & N5(2) \\
\hline $\mathrm{Sc}$ & 4.66 & 13.6 & 4.7 & 4.34 & 4.68 & 4.04 & 9.19 & 4.03 & 7.73 & 8.46 \\
\hline $\mathrm{V}$ & 34.64 & 106.38 & 81.73 & 93.6 & 72.67 & 70.36 & 87 & 27.7 & 77.38 & 74.73 \\
\hline $\mathrm{Cr}$ & 64.04 & 81.95 & 25.03 & 30.63 & 26.81 & 21.53 & 130.97 & 32.14 & 102.05 & 26.72 \\
\hline Co & 117.22 & 45.12 & 85.81 & 123.9 & 124.44 & 82.41 & 43.4 & 133.5 & 54.38 & 98.55 \\
\hline $\mathrm{Ni}$ & 20.1 & 71.45 & 17.84 & 24.41 & 13.65 & 13.59 & 84.84 & 13.37 & 85.78 & 15.94 \\
\hline $\mathrm{Cu}$ & 13.88 & 21.2 & 11.87 & 13.23 & 11.71 & 12.67 & 14.25 & 12.71 & 15.37 & 10.31 \\
\hline $\mathrm{Zn}$ & 50.04 & 39.76 & 26.03 & 35.55 & 22.08 & 27.01 & 41.63 & 27.81 & 29.42 & 24.762 \\
\hline $\mathrm{Ga}$ & 5.31 & 13.19 & 5.98 & 5.09 & 5.17 & 4.34 & 11.79 & 3.75 & 11.26 & 4.03 \\
\hline $\mathrm{Rb}$ & 23.39 & 45.69 & 28.87 & 23.56 & 26.17 & 21.12 & 51.78 & 18.07 & 55.73 & 17.93 \\
\hline $\mathrm{Sr}$ & 176.33 & 381.97 & 152.48 & 142.54 & 164.25 & 136.94 & 191.37 & 186.44 & 191.25 & 147.18 \\
\hline $\mathrm{Y}$ & 12.4 & 27.75 & 18.23 & 16.52 & 16.6 & 15.61 & 21.3 & 18.68 & 17.64 & 24.15 \\
\hline $\mathrm{Zr}$ & 123.9 & 207.34 & 118.37 & 115.46 & 113.05 & 133.06 & 188.11 & 243.27 & 163.65 & 133.93 \\
\hline $\mathrm{Nb}$ & 6.6 & 8.26 & 7.22 & 7.49 & 7.08 & 8.21 & 9.39 & 7.575 & 7.09 & 8.82 \\
\hline Cs & 1.08 & 3.24 & 1.22 & 0.95 & 1.03 & 0.84 & 2.72 & 0.75 & 2.63 & 0.73 \\
\hline $\mathrm{Ba}$ & 151.28 & 196.61 & 146.82 & 133.72 & 135.81 & 120.59 & 248.7 & 117.71 & 282.73 & 120.11 \\
\hline $\mathrm{Hf}$ & 3.49 & 6.79 & 3.45 & 3.14 & 3.35 & 3.9 & 5.62 & 7.25 & 5.02 & 4.21 \\
\hline $\mathrm{Ta}$ & 1.3 & 0.79 & 1 & 1.15 & 1.08 & 1.02 & 0.82 & 1.44 & 0.82 & 1.18 \\
\hline $\mathrm{Pb}$ & 17.33 & 15.47 & 11.04 & 10.71 & 11.28 & 10.17 & 14.8 & 15.67 & 13.03 & 10.38 \\
\hline Th & 3.41 & 8.49 & 5.16 & 5.97 & 4.95 & 5.24 & 7.39 & 7.25 & 6.08 & 8.69 \\
\hline $\mathrm{U}$ & 2.81 & 5.07 & 8.22 & 8.75 & 15.84 & 15 & 21.15 & 0 & 43.15 & 49.55 \\
\hline \multicolumn{11}{|c|}{$\begin{array}{l}\text { Trace element } \\
\text { ratios }\end{array}$} \\
\hline $\mathrm{Cu} / \mathrm{Zn}$ & 0.27 & 0.53 & 0.45 & 0.37 & 0.53 & 0.46 & 0.34 & 0.45 & 0.52 & 0.41 \\
\hline $\mathrm{Sc} / \mathrm{Cr}$ & 0.07 & 0.16 & 0.18 & 0.14 & 0.17 & 0.18 & 0.07 & 0.12 & 0.07 & 0.31 \\
\hline $\mathrm{V} / \mathrm{Cr}$ & 0.54 & 1.29 & 3.26 & 3.05 & 2.71 & 3.26 & 0.66 & 0.86 & 0.75 & 2.79 \\
\hline $\mathrm{Ni} / \mathrm{Co}$ & 0.17 & 1.58 & 0.2 & 0.19 & 0.1 & 0.16 & 1.95 & 0.1 & 1.57 & 0.16 \\
\hline $\mathrm{Cr} / \mathrm{Th}$ & 18.79 & 9.64 & 4.84 & 5.13 & 5.41 & 4.11 & 17.71 & 4.43 & 16.79 & 3.07 \\
\hline $\mathrm{Th} / \mathrm{Sc}$ & 0.73 & 0.06 & 1.03 & 1.37 & 1.05 & 1.29 & 0.8 & 4.02 & 0.78 & 1.02 \\
\hline Th/Co & 0.02 & 0.18 & 0.06 & 0.04 & 0.03 & 0.06 & 0.17 & 0.05 & 0.11 & 0.08 \\
\hline $\mathrm{Th} / \mathrm{U}$ & 1.21 & 1.67 & 0.63 & 0.68 & 0.31 & 0.35 & 0.35 & 0.00 & 0.14 & 0.18 \\
\hline $\mathrm{Zr} / \mathrm{Y}$ & 9.99 & 7.47 & 6.49 & 6.99 & 6.81 & 8.52 & 8.83 & 13.02 & 9.28 & 5.55 \\
\hline $\mathrm{Zr} / \mathrm{Hf}$ & 35.50 & 30.54 & 34.31 & 36.77 & 33.75 & 34.12 & 33.47 & 33.55 & 32.60 & 31.81 \\
\hline $\mathrm{Cr} / \mathrm{Ni}$ & 3.19 & 1.15 & 1.40 & 1.25 & 1.96 & 1.58 & 1.54 & 2.40 & 1.19 & 1.68 \\
\hline
\end{tabular}


Table 7. Trace element concentration (in ppm) and some trace element ratios of the Tipam sandstones of Dilli area.

\begin{tabular}{|c|c|c|c|c|c|c|c|c|c|c|}
\hline \multirow{2}{*}{$\begin{array}{c}\text { Trace } \\
\text { elements }\end{array}$} & \multicolumn{10}{|c|}{ SAMPLE Nos. } \\
\hline & D25 & D30 & D34 & D41 & BP14 & BP19 & NB9 & NB14 & B5 & B12 \\
\hline Sc & 7.79 & 11.33 & 8.18 & 8.81 & 6.9 & 9.26 & 7.08 & 7.68 & 8.33 & 10.26 \\
\hline $\mathrm{V}$ & 79.55 & 118.28 & 58.94 & 70.92 & 48.54 & 68.46 & 47.82 & 51.09 & 51.19 & 72.61 \\
\hline $\mathrm{Cr}$ & 49.29 & 91.98 & 56.86 & 58.05 & 59.3 & 58.49 & 79.74 & 49.78 & 52.17 & 76.6 \\
\hline Co & 46.29 & 55.47 & 60.24 & 53.39 & 59.38 & 42.88 & 38.63 & 41.08 & $34 . .85$ & 38.17 \\
\hline $\mathrm{Ni}$ & 37.64 & 49.1 & 36.11 & 30.38 & 37.4 & 48.3 & 31.91 & 35.05 & 37.81 & 42.7 \\
\hline $\mathrm{Cu}$ & 11.31 & 13.12 & 9.41 & 9.97 & 10.81 & 12.1 & 10.49 & 9.86 & 10.47 & 12.98 \\
\hline $\mathrm{Zn}$ & 27.98 & 32.5 & 25.79 & 31.95 & 21.52 & 30.26 & 24.98 & 23.45 & 26.71 & 55.24 \\
\hline $\mathrm{Ga}$ & 11.25 & 15.21 & 10.29 & 11.87 & 10.65 & 14.29 & 9.53 & 10.49 & 11.06 & 12.64 \\
\hline $\mathrm{Rb}$ & 61.52 & 71.99 & 56.11 & 59.66 & 6.49 & 79.89 & 53.34 & 58.26 & 59.47 & 62.21 \\
\hline $\mathrm{Sr}$ & 227.92 & 181.33 & 223.3 & 178.1 & 255.13 & 145.39 & 229.9 & 226.94 & 219.62 & 177.47 \\
\hline $\mathrm{Y}$ & 23.54 & 30.36 & 22.85 & 32.02 & 25.44 & 23.81 & 27.29 & 21.77 & 24.35 & 33.13 \\
\hline $\mathrm{Zr}$ & 79.34 & 357.84 & 69.47 & 86.52 & 58.71 & 105.5 & 61.53 & 95.96 & 90.72 & 101.85 \\
\hline $\mathrm{Nb}$ & 8.12 & 11.44 & 8.49 & 12.23 & 5.13 & 9.06 & 7.63 & 7.51 & 8.42 & 12.16 \\
\hline Cs & 2.79 & 3.04 & 2.6 & 2.28 & 1.99 & 3.72 & 1.57 & 2.66 & 2.76 & 2.72 \\
\hline $\mathrm{Ba}$ & 311.07 & 414.72 & 294.96 & 321.5 & 425.19 & 423.4 & 371.77 & 301.97 & 308.66 & 353.68 \\
\hline $\mathrm{Hf}$ & 2.84 & 3.8 & 2.72 & 3.29 & 2.11 & 3.17 & 2.13 & 3.43 & 3.38 & 3.71 \\
\hline $\mathrm{Ta}$ & 0.86 & 1.22 & 1.1 & 1.03 & 0.78 & 0.9 & 0.82 & 0.7 & 0.82 & 1.17 \\
\hline $\mathrm{Pb}$ & 10.34 & 11.88 & 11.94 & 13 & 17.29 & 19.59 & 14.55 & 12.7 & 12.25 & 15.53 \\
\hline Th & 8.06 & 16.2 & 9.24 & 11.53 & 7.65 & 9.78 & 11.56 & 7.96 & 8.97 & 15.09 \\
\hline $\mathrm{U}$ & 49.45 & 66.92 & 66.74 & 28.09 & 66.07 & 25.26 & 69.92 & 56.42 & 65.45 & 72.13 \\
\hline \multicolumn{11}{|c|}{$\begin{array}{l}\text { Trace element } \\
\text { ratios }\end{array}$} \\
\hline $\mathrm{Cu} / \mathrm{Zn}$ & 0.4 & 0.4 & 0.36 & 0.31 & 0.5 & 0.4 & 0.42 & 0.42 & 0.39 & 0.23 \\
\hline $\mathrm{Sc} / \mathrm{Cr}$ & 0.15 & 0.12 & 0.14 & 0.15 & 0.11 & 0.15 & 0.08 & 0.15 & 0.15 & 0.13 \\
\hline $\mathrm{V} / \mathrm{Cr}$ & 1.61 & 1.28 & 1.03 & 1.22 & 0.81 & 1.17 & 0.59 & 1.02 & 0.98 & 0.94 \\
\hline $\mathrm{Ni} / \mathrm{Co}$ & 0.81 & 0.88 & 0.59 & 0.56 & 0.62 & 1.12 & 0.82 & 0.85 & 1.08 & 1.11 \\
\hline $\mathrm{Cr} / \mathrm{Th}$ & 6.11 & 5.67 & 6.15 & 5.03 & 7.74 & 5.97 & 6.89 & 6.24 & 5.81 & 5.07 \\
\hline $\mathrm{Th} / \mathrm{Sc}$ & 1.03 & 1.42 & 1.12 & 1.3 & 1.1 & 1.05 & 1.63 & 1.03 & 1.07 & 1.47 \\
\hline $\mathrm{Th} / \mathrm{Co}$ & 0.17 & 0.29 & 0.15 & 0.21 & 0.12 & 0.22 & 0.29 & 0.19 & 0.25 & 0.39 \\
\hline $\mathrm{Th} / \mathrm{U}$ & 0.16 & 0.24 & 0.14 & 0.41 & 0.12 & 0.39 & 0.17 & 0.14 & 0.14 & 0.21 \\
\hline $\mathrm{Zr} / \mathrm{Y}$ & 3.37 & 11.79 & 3.04 & 2.70 & 2.31 & 4.43 & 2.25 & 4.41 & 3.73 & 3.07 \\
\hline $\mathrm{Zr} / \mathrm{Hf}$ & 27.94 & 94.17 & 25.54 & 26.30 & 27.82 & 33.28 & 28.89 & 27.98 & 26.84 & 27.45 \\
\hline $\mathrm{Cr} / \mathrm{Ni}$ & 1.31 & 1.87 & 1.57 & 1.91 & 1.59 & 1.21 & 2.50 & 1.42 & 1.38 & 1.79 \\
\hline
\end{tabular}


the present case, $\mathrm{Al}_{2} \mathrm{O}_{3}$ content in Tikak Parbat sandstones is more and $\mathrm{CaO}$ is very less. It means that in this distribution, $\mathrm{Sr}$ content is controlled by the feldspars. In case of the Tipam sandstones, $\mathrm{CaO}$ is more. Here distribution of $\mathrm{Sr}$ is controlled more by the carbonates. Admittance in place of calcium is a dominant process of removal of strontium from magma. Calcite is common cement (Plate 3(b)) in the Tipam Sandstones [52].

$\mathrm{Th}, \mathrm{U}$ and $\mathrm{Th} / \mathrm{U}$ ratio each of them reveal significant information about arenaceous distribution. Concentration of Th for example may be an estimate of the degree of weathering in sedimentary rocks. Both Th and U are relatively immobile during weathering. However, in reworked sediments under aerobic conditions $U$ may be removed from the system thereby increasing the $T h / U$ ratio and the value may be higher than upper crustal igneous values. The Th/U ratio in most upper continental rocks typically ranges between 3.5 and 4.0 (McLennan et al., 1993). As such, in sedimentary rocks, Th/U values higher than 4.0 may indicate intense weathering in the source areas or sedimentary recycling. In the present case, low $\mathrm{Th} / \mathrm{U}$ ratio hint at low intensity weathering. Relatively, weathering was more intense in Tikak Parbat sandstones. Low Th/U ratios on the other hand are commonly seen in active margin settings where rapid accumulation and burial of sediments can occur.

Positive correlations have been obtained for $\mathrm{TiO}_{2}$ with $\mathrm{Y}, \mathrm{Zr}$ and $\mathrm{Nb}$. In case of Tikak Parbat sandstones $\mathrm{R}^{2}=0.4$ for $\mathrm{Y}, 0.109$ for $\mathrm{Zr}$ and 0.843 for Nb. For Tipam sandstones $\mathrm{R}^{2}=0.618$ for $\mathrm{Y}, 0.344$ for $\mathrm{Zr}$ and 0.907 for $\mathrm{Nb}$. These patterns suggest that the abundance of these components were controlled by the detrital heavy mineral fraction in case of Tipam sandstones while there were some other contributors for Tikak Parbat sandstones.

Vanadium often occurs in organic matter and is best preserved under low $\mathrm{pH}$ and high reducing conditions [53]. Organic matter derived from marine planktons is known to concentrate vanadium. The high vanadium level in most of the samples of Tikak Parbat sandstone and Tipam sandstones suggests organic derivation too. Dypiv [54] opines that the $\mathrm{V} / \mathrm{Cr}$ ratios of sediments are indicators of the ventilation conditions in the depositional environment. The values for the Tikak Parbat and Tipam sandstones indicate low ventilation conditions in the depositional basin which resulted in poor to moderate sorting of these sediments. The $\mathrm{V} / \mathrm{Cr}$ ratio of Tikak Parbat sandstone varies from $<2$ to $>2$ indicating occurrence of anoxic and oxic depositional condition. In Tipam sandstones the ratio is $<2$ which indicates an oxic depositional condition [55]. The Ni/Co ratio helps interpret Eh conditions in the depositional basin which may have been a mixed environment in the present case. Similar observations were noticed in Disang sandstones of Nagaland [56]. The low values of $\mathrm{Cu} / \mathrm{Zn}$ ratio suggest increased oxidising condition.

The plots of $\mathrm{Zr}$ versus $\mathrm{TiO}_{2}$ after Hayashi et al. [57], show that the source rocks of both the sandstones are felsic igneous rocks (Figure 8). According to Bhatia and Crook [5] the triangular plots of the elements Th-Sc-Zr/10 show 
excellent discrimination of tectonic settings. In the triangular diagram of Th-Sc$\mathrm{Zr} / 10$ for Tikak Parbat Sandstone most of the plots concentrate in PM to CIA while the Tipam Sandstone plots are close to CIA and ACM (Figure 9).

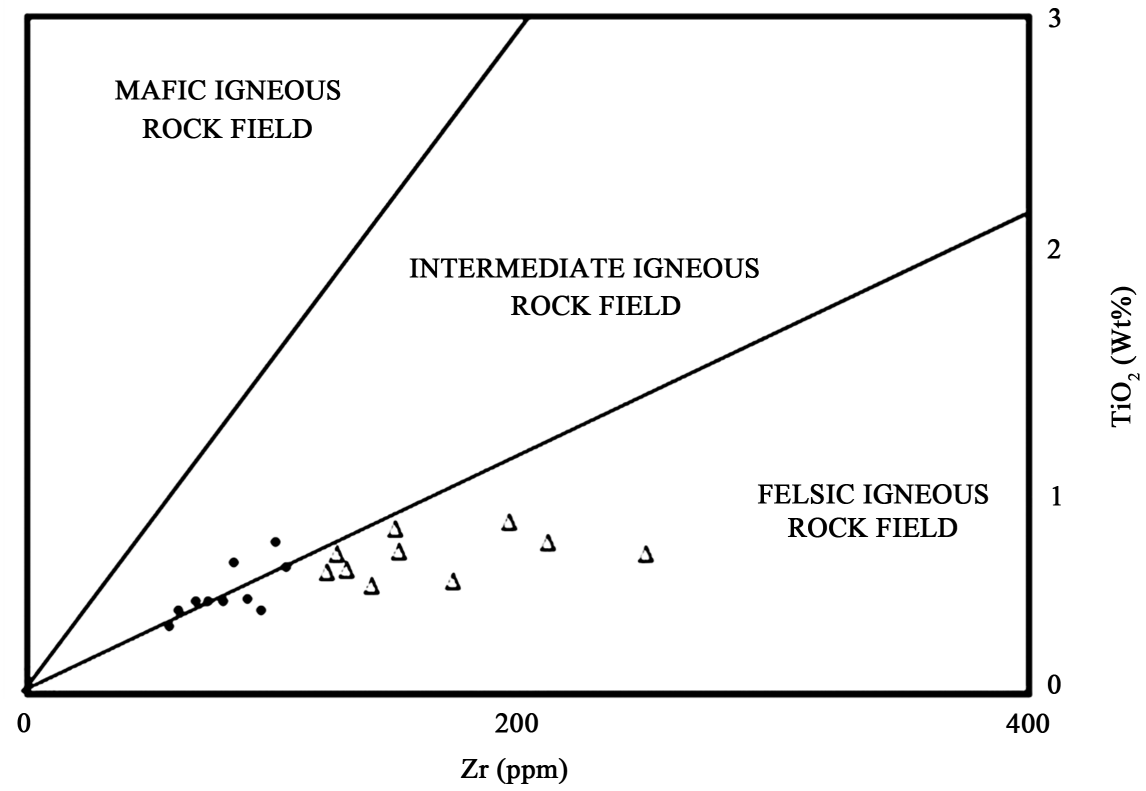

Figure 8. $\mathrm{Zr}(\mathrm{ppm})$ vs $\mathrm{TiO}_{2}$ (wt\%) plot of the Tikak Parbat sandstones $(\Delta)$ and Tipam sandstones $(\bullet)$ showing Mafic, Intermediate and Felsic Igneous rock fields after Hayashi et al., 1997.

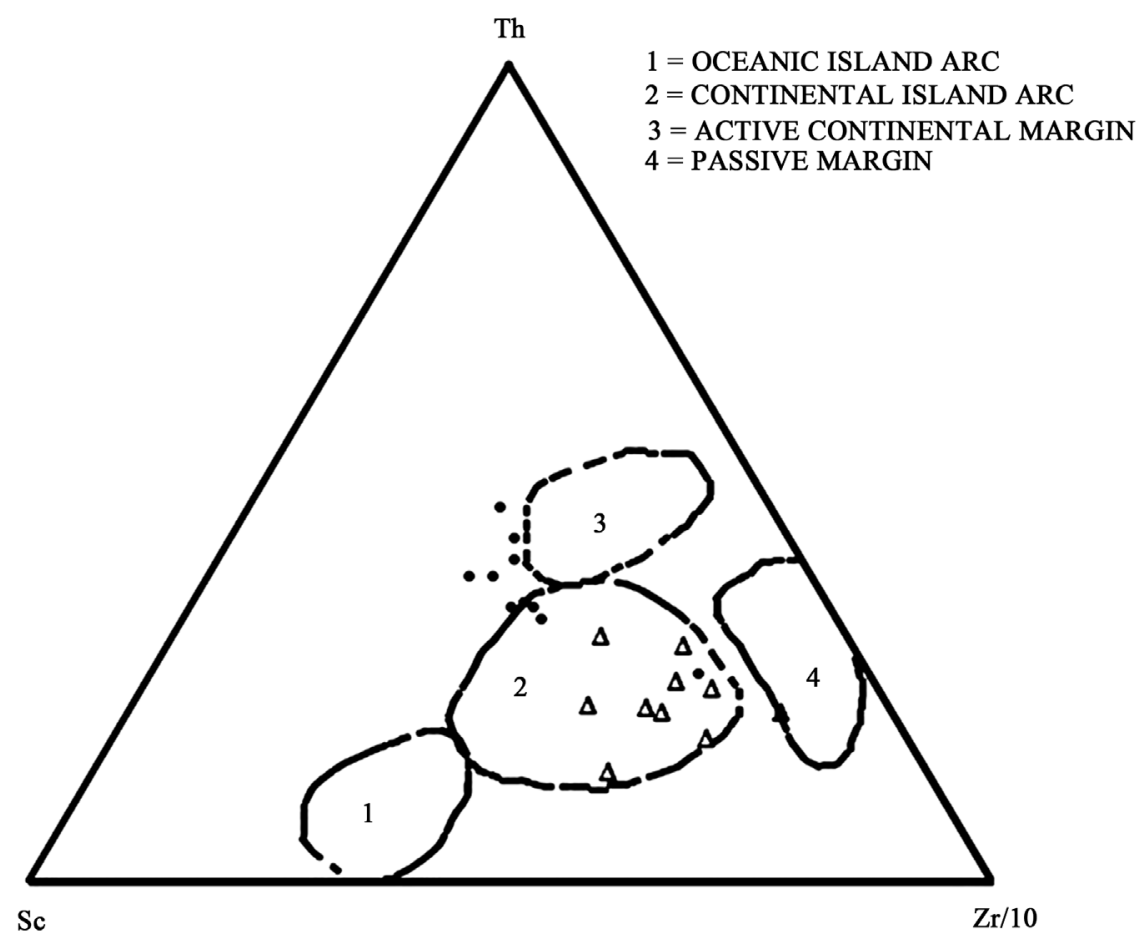

Figure 9. Th-Sc-Zr/10 plot of the Tikak Parbat sandstones $(\Delta)$ and Tipam sandstones $(\bullet)$, (cf. Bhatia and Crook, 1986). 


\subsection{Rare Earth Elements}

Rare earth elements (REE) behave as an unusually coherent group of elements and are amongst the least soluble elements that are relatively immobile during weathering, low-grade metamorphism and hydrothermal alteration. The rare earth elements have very low residence time in sea water and their concentration in the ocean is exceedingly low. Most common sedimentary processes do not significantly affect the rare earth element distribution in sedimentary rocks [58]. Rare earth elemental distribution in the upper continental crust is widely assumed to be similar to that of clastic sediments [59]. The abundance of REE and some elemental ratios of both Tikak Parbat sandstones and Tipam sandstones of the study area are listed in Table 8 and Table 9, respectively.

The Tikak Parbat sandstones show a large variation in REE content (66.02 to $174.04 \mathrm{ppm}$ ) while the Tipam sandstones show less variation in REE content

Table 8. Rare earth element concentration (in ppm) and some REE ratios of the Tikak Parbat sandstones of Dilli area.

\begin{tabular}{|c|c|c|c|c|c|c|c|c|c|c|}
\hline \multirow{2}{*}{$\begin{array}{c}\text { Rare Earth } \\
\text { Elements (REE) }\end{array}$} & \multicolumn{10}{|c|}{ SAMPLE Nos. } \\
\hline & D9 & D12 & D16 & D19 & BP5 & BP9 & NB2 & NB5 & N4(1) & N5(2) \\
\hline $\mathrm{La}$ & 12.61 & 22.93 & 19.84 & 23.58 & 18.5 & 20.08 & 21.39 & 29.81 & 16.68 & 32.31 \\
\hline $\mathrm{Ce}$ & 26.92 & 47.27 & 45.58 & 53.58 & 40.76 & 46.62 & 43.61 & 65.72 & 35.38 & 72.11 \\
\hline $\operatorname{Pr}$ & 3.16 & 5.85 & 5.54 & 6.73 & 4.99 & 5.55 & 5.45 & 8.1 & 4.33 & 8.87 \\
\hline $\mathrm{Nd}$ & 12.01 & 22.08 & 21.47 & 25.29 & 18.83 & 21.02 & 20.48 & 30.4 & 15.98 & 34.13 \\
\hline $\mathrm{Sm}$ & 2.47 & 4.67 & 4.71 & 5.27 & 4.06 & 4.51 & 4.35 & 6.06 & 3.38 & 7.1 \\
\hline $\mathrm{Eu}$ & 0.67 & 1.13 & 1.12 & 1.18 & 0.95 & 0.99 & 1.09 & 1.27 & 0.89 & 1.42 \\
\hline $\mathrm{Gd}$ & 2.32 & 4.46 & 4.14 & 4.43 & 3.73 & 4.03 & 4.02 & 5.33 & 3.2 & 6.08 \\
\hline $\mathrm{Tb}$ & 0.42 & 0.83 & 0.71 & 0.7 & 0.63 & 0.64 & 0.75 & 0.84 & 0.62 & 0.97 \\
\hline Dy & 2.42 & 5.16 & 3.66 & 3.48 & 3.34 & 3.35 & 4.27 & 3.98 & 3.48 & 5.04 \\
\hline Ho & 0.44 & 0.94 & 0.6 & 0.57 & 0.59 & 0.54 & 0.71 & 0.67 & 0.63 & 0.85 \\
\hline $\mathrm{Er}$ & 1.19 & 2.68 & 1.64 & 1.57 & 1.56 & 1.49 & 2.12 & 1.85 & 1.87 & 2.45 \\
\hline $\mathrm{Tm}$ & 0.18 & 0.43 & 0.22 & 0.21 & 0.27 & 0.21 & 0.34 & 0.25 & 0.29 & 0.36 \\
\hline $\mathrm{Yb}$ & 1.05 & 2.59 & 1.29 & 1.18 & 1.28 & 1.22 & 2 & 1.51 & 1.71 & 2.06 \\
\hline $\mathrm{Lu}$ & 0.16 & 0.38 & 0.19 & 0.18 & 0.19 & 0.18 & 0.29 & 0.22 & 0.26 & 0.29 \\
\hline \multicolumn{11}{|l|}{ REE ratios } \\
\hline$\Sigma \mathrm{REE}$ & 66.02 & 121.4 & 110.71 & 127.95 & 99.68 & 110.43 & 110.87 & 156.01 & 88.7 & 174.04 \\
\hline$\Sigma$ LREE & 57.84 & 103.93 & 98.26 & 115.63 & 88.09 & 98.77 & 96.37 & 141.36 & 76.64 & 155.94 \\
\hline$\Sigma$ HREE & 8.18 & 17.47 & 12.45 & 12.32 & 11.59 & 11.66 & 14.5 & 14.65 & 12.06 & 18.1 \\
\hline$\Sigma$ LREE/ $\Sigma$ HREE & 7.07 & 5.95 & 7.89 & 9.39 & 7.60 & 8.47 & 6.65 & 9.65 & 6.35 & 8.62 \\
\hline $\mathrm{Eu} / \mathrm{Eu}^{*}$ & 0.09 & 0.08 & 0.08 & 0.08 & 0.08 & 0.08 & 0.08 & 0.07 & 0.09 & 0.07 \\
\hline $\mathrm{La} / \mathrm{Yb}$ & 12.01 & 8.85 & 15.38 & 19.98 & 14.45 & 16.46 & 10.70 & 19.74 & 9.75 & 15.68 \\
\hline $\mathrm{La} / \mathrm{Y}$ & 1.01 & 0.82 & 1.08 & 1.42 & 1.11 & 1.28 & 1 & 1.59 & 0.94 & 1.33 \\
\hline
\end{tabular}


Table 9. Rare earth element concentration (in ppm) and some REE ratios of the Tipam Sandstones of Dilli area.

\begin{tabular}{|c|c|c|c|c|c|c|c|c|c|c|}
\hline \multirow{2}{*}{$\begin{array}{c}\text { Rare Earth } \\
\text { Elements (REE) }\end{array}$} & \multicolumn{10}{|c|}{ SAMPLE Nos. } \\
\hline & $\mathrm{D} 25$ & D30 & D34 & D41 & BP14 & BP19 & NB9 & NB14 & B5 & B12 \\
\hline $\mathrm{La}$ & 22.14 & 38.84 & 26.41 & 35.18 & 22.83 & 25.14 & 39.84 & 23.13 & 26.91 & 35.27 \\
\hline $\mathrm{Ce}$ & 44.92 & 77.21 & 53.21 & 71.35 & 47.24 & 51.84 & 77.26 & 45.94 & 55.24 & 71.49 \\
\hline $\operatorname{Pr}$ & 5.36 & 8.87 & 6.31 & 8.47 & 5 & 6.09 & 8.11 & 5.49 & 6.57 & 8.29 \\
\hline $\mathrm{Nd}$ & 19.39 & 31.22 & 23.19 & 30.43 & 18.04 & 22.4 & 27.08 & 19.63 & 23.82 & 29.71 \\
\hline $\mathrm{Sm}$ & 3.96 & 6.13 & 4.59 & 6.09 & 3.57 & 4.47 & 4.76 & 3.92 & 4.67 & 5.86 \\
\hline $\mathrm{Eu}$ & 0.96 & 1.33 & 1.07 & 1.38 & 1.11 & 1.16 & 1.13 & 0.98 & 1.15 & 1.35 \\
\hline Gd & 3.96 & 5.76 & 4.21 & 5.78 & 3.94 & 4.33 & 4.96 & 3.83 & 4.69 & 5.73 \\
\hline $\mathrm{Tb}$ & 0.71 & 1.01 & 0.76 & 1.07 & 0.74 & 0.79 & 0.84 & 0.7 & 0.79 & 0.99 \\
\hline Dy & 4.22 & 5.69 & 4.09 & 6.03 & 4.23 & 4.47 & 4.74 & 3.9 & 4.57 & 5.88 \\
\hline Ho & 0.79 & 1.07 & 0.76 & 1.11 & 0.83 & 0.85 & 0.89 & 0.72 & 0.85 & 1.13 \\
\hline Er & 2.26 & 3.26 & 2.2 & 3.18 & 2.45 & 2.44 & 2.64 & 2.15 & 2.41 & 3.22 \\
\hline $\mathrm{Tm}$ & 0.35 & 0.49 & 0.34 & 0.48 & 0.38 & 0.38 & 0.39 & 0.32 & 0.36 & 0.52 \\
\hline $\mathrm{Yb}$ & 2.01 & 3.08 & 1.94 & 2.83 & 2.26 & 2.22 & 2.42 & 1.92 & 1.99 & 2.96 \\
\hline $\mathrm{Lu}$ & 0.31 & 0.43 & 0.31 & 0.39 & 0.33 & 0.34 & 0.36 & 0.28 & 0.31 & 0.45 \\
\hline \multicolumn{11}{|l|}{ REE ratios } \\
\hline$\Sigma \mathrm{REE}$ & 111.34 & 184.39 & 129.39 & 173.77 & 112.95 & 126.92 & 175.42 & 112.91 & 134.33 & 172.85 \\
\hline$\Sigma$ LREE & 96.73 & 163.6 & 114.78 & 152.9 & 97.79 & 111.1 & 158.18 & 99.09 & 118.36 & 151.97 \\
\hline$\Sigma$ HREE & 14.61 & 20.79 & 14.61 & 20.87 & 15.16 & 15.82 & 17.24 & 13.82 & 15.97 & 20.88 \\
\hline$\Sigma$ LREE/ $\Sigma$ HREE & 6.62 & 7.87 & 7.86 & 7.33 & 6.45 & 7.02 & 9.18 & 7.17 & 7.41 & 7.28 \\
\hline $\mathrm{Eu} / \mathrm{Eu}^{*}$ & 0.08 & 0.07 & 0.08 & 0.08 & 0.1 & 0.09 & 0.08 & 0.08 & 0.08 & 0.08 \\
\hline $\mathrm{La} / \mathrm{Yb}$ & 11.01 & 12.61 & 13.61 & 12.43 & 10.10 & 11.32 & 16.46 & 12.05 & 13.52 & 11.92 \\
\hline $\mathrm{La} / \mathrm{Y}$ & 0.94 & 1.27 & 1.15 & 1.09 & 0.89 & 1.05 & 1.45 & 1.06 & 1.1 & 1.06 \\
\hline
\end{tabular}

(111.34 to $184.39 \mathrm{ppm}$ ). A strong assumption on the sorting processes during sedimentation is that fine grained sediments tend to have the relative abundance of REE as found in their source region [45] [60]. Sand fraction tends to have low REE content.

The $\Sigma$ LREE/ $\Sigma$ HREE ratio of Tikak Parbat sandstones varies from 5.95 to 9.65 with an average of 7.76 and that of Tipam sandstone varies from 6.45 to 9.18 with an average of 7.42 which are almost similar to that of the UCC. The high ratio of $\Sigma$ LREE/ $\Sigma$ HREE in both the sandstones suggest source rock area to be granitic [61].

The chondrite normalized REE patterns of the Tikak Parbat sandstone (Figure 10(a)) and the Tipam sandstone (Figure 10(b)) are similar in nature and bears resemblance with the UCC for most rare earth elements. The chondrite normalized REE distribution pattern of the sandstones exhibits a mod- 


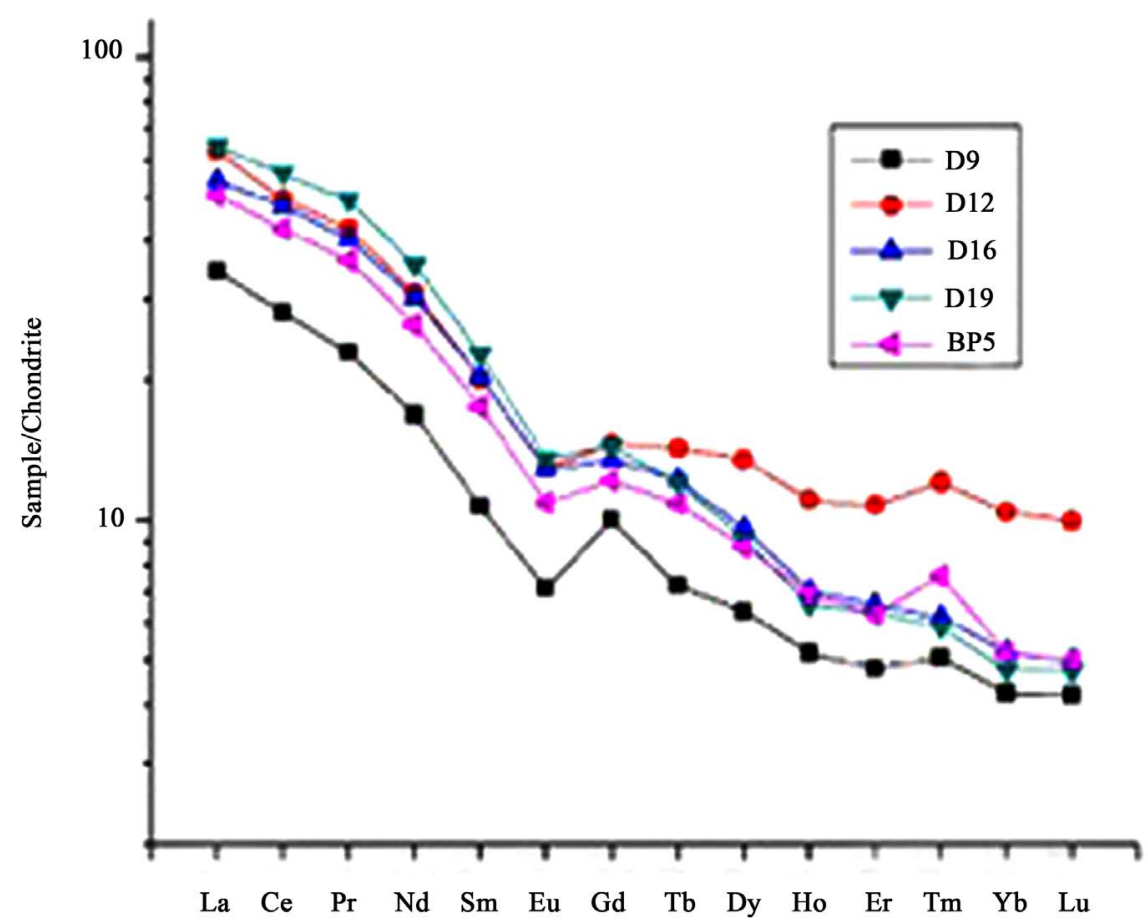

(a)

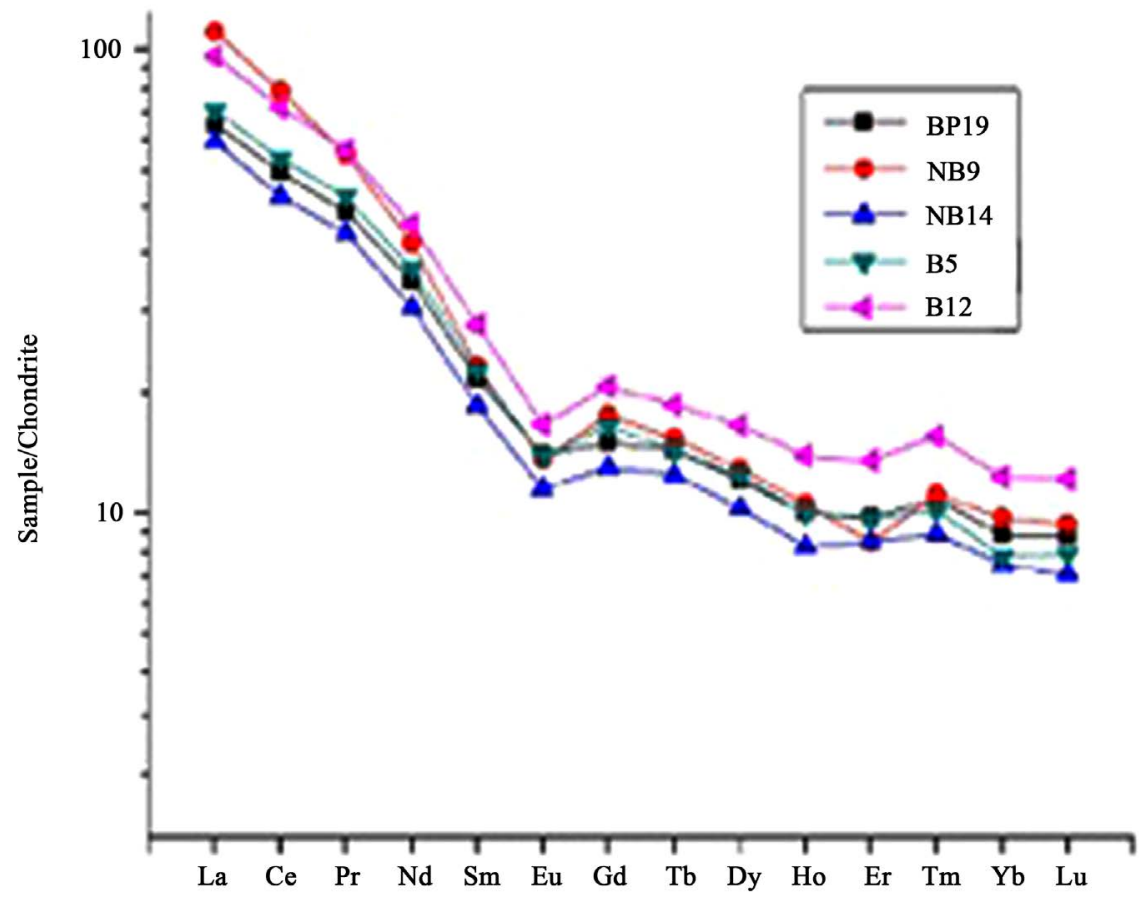

(b)

Figure 10. REE distribution pattern of: (a) Tikak Parbat sandstone; and (b) Tipam sandstone.

erately steep slope, which suggests enrichment in LREE and depletion of HREE. These patterns also show negative $\mathrm{Eu}$ anomaly. Intracrustal fractionation and separation of plagioclase impart the negative Eu anomaly in the upper crust [20]. 
Such chondrite normalized REE distribution patterns and negative Eu anomaly indicate their derivation from granitic and granodioritic type plutonic source rocks [20] [59] [62]. The negative Eu anomalies in the sediments indicate preferential removal of plagioclase feldspar due to weathering. Plagioclase is known to be more rapidly destroyed than either quartz or K-feldspar in weathering profiles [63].

Variable $\mathrm{La} / \mathrm{Yb}$ ratio of the sandstones indicates differing proportions of felsic rocks in the source. Bhatia [64] worked out the discriminating rare earth elements characteristics of different sedimentary basins based on REE content and $\mathrm{La} / \mathrm{Yb}$ ratio. The average $\mathrm{La} / \mathrm{Yb}$ ratio of Tikak Parbat sandstones is 14.3 which is very close to passive margin (15.9) tectonic setting. The average La/Yb ratio of Tipam sandstones is 12.5 which is same as active continental margin (12.5) tectonic setting. The La-Th-Sc ternary discriminating plots after Bhatia and Crook (1986) which otherwise is a very useful indicator of tectonic environment shows plots of both the sandstones spread out in the ACM and PM fields. However, a few plots of Tikak Parbat Sandstones fall in the CIA field as well (Figure 11).

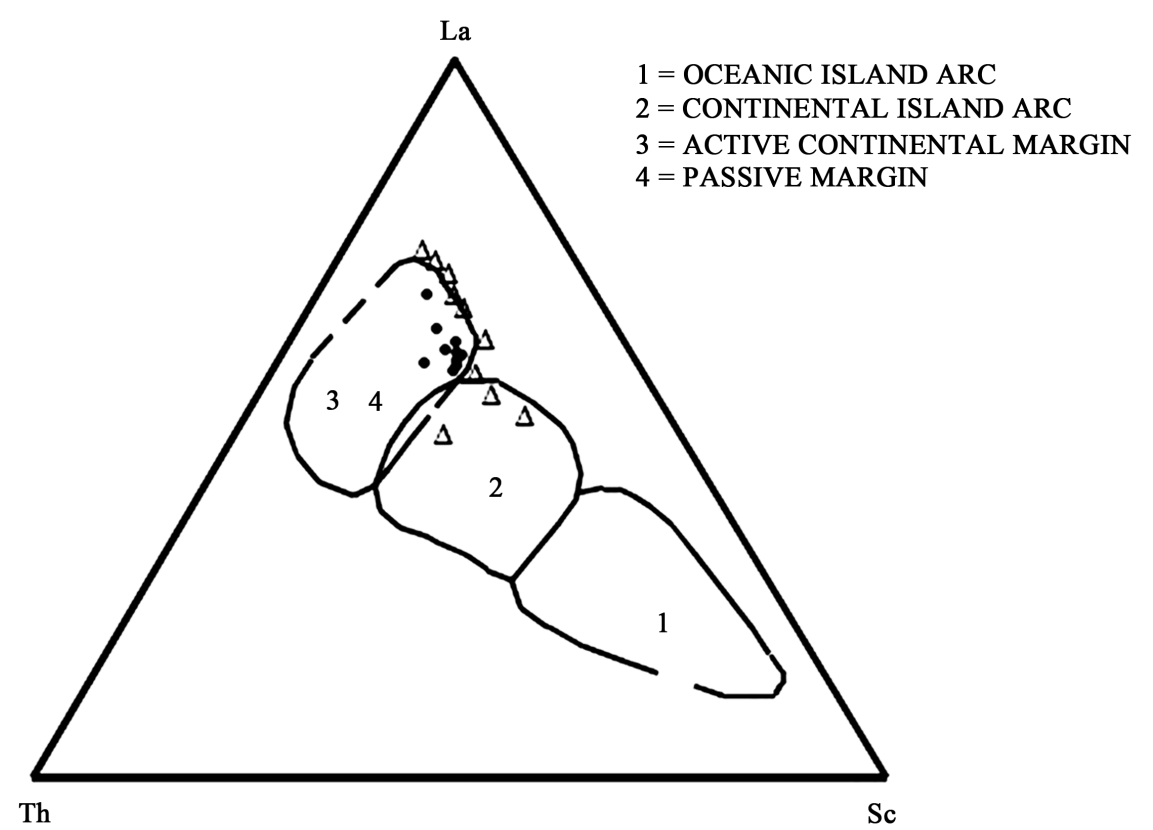

Figure 11. La-Th-Sc plot of the Tikak Parbat Sandstones $(\Delta)$ and Tipam Sandstones $(\bullet)$ (cf. Bhatia and Crook, 1986).

\section{Conclusions}

The detailed geochemical studies conducted in the present study provide a new understanding about the evolution of the Tikak Parbat and Tipam sandstones of Sivasagar district of Assam. The salient findings from our study stem out along the following concluding observations.

1. Analysis of the major oxides indicates the older Tikak Parbat sandstones to be chemically more matured than the Tipam sandstones, a fact also reflected from petrographic investigations. Sediments of both the sandstones were de- 
rived from upper continental crust and had undergone low levels of recycling. Relatively, sediment contributions were from deeper levels for the $\mathrm{Ti}$ pam sandstones which indicate tectonic rejuvenation at later stages. Climatic conditions were largely humid during the deposition of Tikak Parbat sandstones, while it was arid during the deposition of Tipam sandstones. Variable palaeoclimatic signatures as reflected in petrographic and geochemical plots are mainly due to different parameters involved and framework of the discriminatory plots.

2. Tikak Parbat sandstones are found to be more weathered than the Tipam sandstones. The weathering impressions on the distributions have been modified during the transportation stage.

3. Both the sandstones have been largely derived from granitic (felsic) rocks. Andesitic to granitic sources also contributed towards buildup of Tipam sandstones.

4. Tectonically, Tikak Parbat sandstones are found to have more affinity towards passive margin (PM) setup wherein sediments were mostly contributed from stable continental areas whereas Tipam sandstones express a strong likeness towards active continental margin (ACM) setup to where clasts were supplied from uplifted areas.

5. Both Tikak Parbat and Tipam sandstones are classified as sublitharenite to wacke from geochemical point of view. Finer populations in both the distributions contributed $\mathrm{Al}_{2} \mathrm{O}_{3}$ which led to the concentration of plots in the "“sublitharenite" and "wacke" fields.

6. Trace element composition of both the distributions does not differ much from that of the upper continental crust (UCC) and hint at felsic igneous source rocks. Phyllosilicates and feldspars had more control on the distribution of elements like $\mathrm{Ba}, \mathrm{Rb}$ and $\mathrm{Ni}$ in case of the Tikak Parbat sandstones than the Tipam sandstones. $\mathrm{CaO}$ controlled the distribution of $\mathrm{Sr}$ in case of the Tipam sandstones. Depositional setup had low ventilation and the temporal span was marked by both oxic and anoxic settings.

7. The $\Sigma$ LREE/ $\Sigma$ HREE ratio and chondrite normalized REE patterns of both the sandstones are almost similar to that of the UCC and suggest compositionally granitic type of source rocks. This study shows the LREE as the more enriched entity, while HREE is found to be depleted. A negative Eu anomaly further hints at sediment derivation from upper crust. Affinity of Tikak Parbat sandstones to PM and Tipam sandstones to ACM is also supported by REE.

8. The Tipam sediments were transported over a high gradient topography and rapidly deposited in the area. The sediments were affected by the tectonic upliftment of provenance covering the areas of Naga Patkai Range in the south east and Eastern Himalayas along the syntaxial bend during mid Miocene. Contribution of Mishimi Hills composed mainly of granites and granodioritic rocks in the Tipam sandstone is probably less considering the lower popu- 
lation of $\mathrm{Zr}$ in the Tipam unit. Comparatively the older Tikak Parbat sandstones reflect a stable tectonic setup which later on underwent a phase of volatility leading to the deposition of the Tipam sandstone.

\section{Acknowledgements}

The authors are grateful to the Principal, Arya Vidyapeeth College, Guwahati and Head, Department of Geological Sciences, Gauhati University, Guwahati for the support extended to this work. The XRF analysis for the major oxide was performed in the Wadia Institute of Himalayan Geology, Dehradun. The National Geophysical Research Institute, Hyderabad is acknowledged for their help in conducting the trace elements analyses.

\section{References}

[1] Blatt, H., Middleton, G.V. and Murray, R.C. (1980) Origin of Sedimentary Rocks. 2nd Ed., Prentice-Hall, New Jersey, 634.

[2] Dickinson, W.R. (1985) Interpreting Provenance Relations from Detrital Modes of Sandstones. In: Zuffa, G.C., Ed., Provenance of Arenites, D. Reidel Publishing Company, Dordrecht, The Netherlands, 333-362. https://doi.org/10.1007/978-94-017-2809-6_15

[3] Pettijohn, F.J., Potter, P.E. and Siever, R. (1987) Sand and Sandstone. Springer, New York, 553. https://doi.org/10.1007/978-1-4612-1066-5

[4] Von Eynatten, H. and Gaupp, R. (1999) Provenance of Cretaceous Synorogenic Sandstones in the Eastern Alps: Constraints from Framework Petrography, Heavy Mineral Analysis and Mineral Chemistry. Sedimentary Geology, 124, 81-111. https://doi.org/10.1016/S0037-0738(98)00122-5

[5] Bhatia, M.R. and Crook, K.A.W. (1986) Trace Element Characteristics of Graywackes and Tectonic Setting Discrimination of Sedimentary Basins. Contributions to Mineralogy and Petrology, 92, 181-193. https://doi.org/10.1007/BF00375292

[6] Roser, B.P. and Korsch, R.J. (1986) Determination of Tectonic Setting of Sandstone-Mudstone Suites Using $\mathrm{SiO}_{2}$ Content and $\mathrm{K}_{2} \mathrm{O} / \mathrm{Na}_{2} \mathrm{O}$ Ratio. The Journal of Geology, 94, 635-650. https://doi.org/10.1086/629071

[7] Armstrong-Altrin, J.S., Lee, Y.I., Verma, S.P. and Ramasamy, S. (2004) Geochemistry of Sandstones from the Upper Miocene Kundankulam Formation, Southern India: Implications for Provenance, Weathering, and Tectonic Setting. Journal of Sedimentary Research, 74, 285-297. https://doi.org/10.1306/082803740285

[8] Degens, E.T. (1965) Geochemistry of Sediments. Prentice Hall Inc., New Jersey, 342. https://doi.org/10.1097/00010694-196509000-00025

[9] Condie, K.C. (1993) Chemical Composition and Evolution of Upper Continental Crust: Contrasting Results from Surface Samples and Shales. Chemical Geology, 104, 1-37. https://doi.org/10.1016/0009-2541(93)90140-E

[10] McLennan, S.M. (1989) Rare Earth Elements in Sedimentary Rocks: Influences of Provenance and Sedimentary Processes. Reviews in Mineralogy and Geochemistry, 21, 169-200.

[11] Raza, M., Casshyap, S.M. and Khan, A. (2002) Geochemistry of Mesoproterozoic Lower Vindhyan Shales from Chittaurarh, Southeastern Rajasthan and Its Bearing on Source Rock Composition, Palaeoweathering Conditions and Tectono-Sedimentary Environments. Journal of the Geological Society of India, 60, 505-518. 
[12] Ikhane, P.R., Akintola, A.I., Bankole, S.I. and Oyinboade, Y.T. (2014) Provenance Studies of Sandstone Facies Exposed near Igbile, Southwestern Nigeria: Petrographic and Geochemical Approach. Journal of Geography and Geology, 6, 47-68. https://doi.org/10.5539/jgg.v6n2p47

[13] Basu, A., Young, S.W., Suttner, L.J., James, W.C. and Mack, G.H. (1975) Re-Evaluation of the Use of Undulatory Extinction and Polycrystallinity in Detrital Quartz for Provenance Interpretation. Journal of Sedimentary Petrology, 45, 873-882.

[14] Chayes, F. (1949) A Simple Point Counter for Thin Section Analysis. American Mineralogist, 34, 1-11.

[15] Das, P.K., Lahkar, A.D. and Duarah, B.P. (2008) Petrography of the Tikak Parbat and Tipam Sandstones in and around Dilli, Sivasagar District, Assam, India. Bangladesh Geology Journal, 14, 57-77.

[16] Ingersol, R.V. and Suczek, C.A. (1979) Petrology and Provenance of Neogene Sand from Nicobar and Bangal Fans, DSDP Sites 211 and 218. Journal of Sedimentary Petrology, 49, 1217-1228.

[17] Dickinson, W.R. and Suczek, C.A. (1979) Plate Tectonics and Sandstone Compositions. American Association of Petroleum Geologists' Bulletin, 63, 2164-2182.

[18] Dickinson, W.R., Beard, L.S., Brackenridge, G.R., Erjavek, J.L., Fergusan, R.C., Inman, K.F., Knepp, R.A., Lindberg, F.A. and Royberg, P.T. (1983) Provenance of North American Phanerozoic Sandstones in Relation to Tectonic Setting. Bulletin of the Geological Society of America, 94, 222-235. https://doi.org/10.1130/0016-7606(1983)94\%3C222:PONAPS\%3E2.0.CO;2

[19] Suttner, L.J. and Dutta, P.K. (1986) Alluvial Sandstone Composition and Palaeoclimate Framework Mineralogy. Journal of Sedimentary Petrology, 56, 329-345.

[20] Taylor, S.R. and McLennan, S.M. (1985) The Continental Crust: Its Composition and Evolution. Blackwell, Oxford, UK, 349.

[21] Nath, B.N., Kunzendorf, H. and Pluger, W.L. (2000) Influence of Provenance, Weathering and Sedimentary Processes on the Elemental Ratios of the Fine-Grained Fraction of the Bedload Sediments from the Vembanad Lake and the Adjoining Continental Shelf, Southwest Coast of India. Journal of Sedimentary Research, 70, 1081. https://doi.org/10.1306/100899701081

[22] Reineck, H.E. and Singh, I.B. (1980) Depositional Sedimentary Environments. Springer-Verlag, New York, 549. https://doi.org/10.1007/978-3-642-81498-3

[23] Bhatia, M.R. (1983) Plate Tectonics and Geochemical Composition of Sandstones. Journal of Geology, 91, 611-627. https://doi.org/10.1086/628815

[24] Jenner, G.A., Fryer, B.J. and McLennan, S.M. (1981) Geochemistry of the Archean Yellowknife Supergroup. Geochimica et Cosmochimica Acta, 45, 1111-1129. https://doi.org/10.1016/0016-7037(81)90135-6

[25] Nesbitt, H.W., Markovics, G. and Price, R.C. (1980) Chemical Processes Affecting Alkalies and Alkaline Earths during Continental Weathering. Geochimica et Cosmochimica Acta, 44, 1659-1666. https://doi.org/10.1016/0016-7037(80)90218-5

[26] Cingolani, C.A., Manassero, M. and Abre, P. (2003) Composition, Provenance and Tectonic Setting of Ordovician Siliciclastic Rocks in the San Rafael Block: Southern Extension of the Pre-Cordillera Crustal Fragment, Argentina. Journal of South American Earth Sciences, 16, 91-106. https://doi.org/10.1016/S0895-9811(03)00021-X

[27] Nesbitt, H.W., Fedo, C.M. and Young, G.M. (1997) Quartz and Feldspar Stability, Steady and Non-Steady-State Weathering, and Petrogenesis of Siliclastic Sands and 
Muds. Journal of Geology, 105, 173-191. https://doi.org/10.1086/515908

[28] Nesbitt, H.W. and Young, G.M. (1982) Early Proterozoic Climates and Plate Motions Inferred from Element Chemistry of Lutites. Nature, 299, 715-717. https://doi.org/10.1038/299715a0

[29] Harnois, L. (1988) The New Index, a New Chemical Index of Weathering. Sedimentary Geology, 55, 319-322. https://doi.org/10.1016/0037-0738(88)90137-6

[30] Fedo, C.M., Nesbitt, H.W. and Young, G.M. (1995) Unraveling the Effects of Potassium Metasomatism in Sedimentary Rocks and Paleosols, with Implications for Weathering Conditions and Provenance. Geology, 23, 921-924. https://doi.org/10.1130/0091-7613(1995)023\%3C0921:UTEOPM\%3E2.3.CO;2

[31] Cullers, R.L., Basu, A. and Suttner, L.J. (1988) Geochemical Signature of Provenance in Sand-Size Material in Soils and Stream Sediments near the Tobacco Root Batholith, Montana, USA. Chemical Geology, 70, 335-348. https://doi.org/10.1016/0009-2541(88)90123-4

[32] Condie, K.C. (1967) Geochemistry of Early Precambrian Greywacke from Wyoming. Geochimica et Cosmochimica Acta, 321, 2136-2147.

[33] Le Maitre, R.W. (1976) The Chemical Variability of Some Common Igneous Rocks. Journal of Petrology, 17, 589-637. https://doi.org/10.1093/petrology/17.4.589

[34] Kumar, G. (1997) Geology of Arunachal Pradesh. Geological Society, India, 217.

[35] Dutta, S.K. (1982) Tertiary Stratigraphy of Upper Assam. Journal Palaeontological Society of India, Special Publication, 1, 65-83.

[36] Handique, G.K., Dutta, S.K. and Neog, A. (1992) Stratigraphy, Depositional Environment and Hydrocarbon Prospects in Moran Oil Field, Upper Assam. Geophytology, 22, 217-228.

[37] Talukdar, S.C. and Mazumdar, A.K. (1983) Geology of the Abor Volcanic Rocks, Sian District, Arunachal Praesh. Geological Survey of India, (Miscellaneous Publication), 43, 135-138.

[38] Anon (1974) Geology and Mineral Resource of the States of India-Assam and Adjoining States. Geological Survey of India, (Miscellaneous Publication), 30, 1-24.

[39] Uddin, A. and Lundberg, N. (1998) Unroofing History of the Eastern Himalaya and the Indo-Burma Bangladesh Ranges: Heavy Mineral Study of Cenozoic Sediments from the Bengal Basin. Journal of Sedimentary Research, 68, 465-472. https://doi.org/10.2110/jsr.68.465

[40] Lahkar, A.D. (2007) Sedimentological Studies of Tertiary Sediments of Dilli Area, Sibsagar District, Assam. Unpublished, PhD Thesis, Gauhati University, Guwahati, 147.

[41] McLennan, S.M., Hemming, S., McDaniel, D.K. and Hanson, G.N. (1993) Geochemical Approaches to Sedimentation, Provenance, and Tectonics. Special Papers: Geological Society of America, 21.

[42] Phillips, E. (1991) The Lithostratigraphy, Sedimentology and Tectonic Setting of the Monian Supergroup, Western Anglesey, North Wales. The Geological Society of London, 148, 1079-1090. https://doi.org/10.1144/gsjgs.148.6.1079

[43] Crook, K.A.W. (1974) Lithogenesis and Geotectonic: The Significance of Compositional Variations in Flysch Arenites (Graywackes). SEPM (Society for Sedimentary Geology Special Publication), 19, 304-310.

[44] Herron, M.M. (1988) Geochemical Classifications of Terrigenous Sands and Shales from Core or Log Data. Journal Sedimentary Petrology, 58, 820-829.

[45] McLennan, S.M., Taylor, S.R., McCulloch, M.T. and Maynard, J.B. (1990) Geo- 
chemical and Nd-Sr Isotopic Composition of Deep-Sea Turbidities: Crustal Evolution and Plate Tectonic Associations. Geochimica et Cosmochimica Acta, 54, 2015-2050. https://doi.org/10.1016/0016-7037(90)90269-Q

[46] McLennan, S.M. (2001) Relationships between the Trace Element Composition of Sedimentary Rocks and Upper Continental Crust. Geochemistry, Geophysics, Geosystems, 2. https://doi.org/10.1029/2000GC000109

[47] McLennan, S.M., Taylor, S.R. and Eriksson, K.A. (1983) Geochemistry of Archean Shales from the Pilbara Supergroup, Western Australia. Geochimica et Cosmochimica Acta, 47, 1211-1222. https://doi.org/10.1016/0016-7037(83)90063-7

[48] López, J.M.G., Bauluz, B., Fernández-Nieto, C. and Oliete, A.Y. (2005) Factors Controlling the Trace-Element Distribution in Fine-Grained Rocks: The Albian Kaolinite-Rich Deposits of the Oliete Basin (NE Spain). Chemical Geology, 214, 1-19. https://doi.org/10.1016/j.chemgeo.2004.08.024

[49] Bhat, M.I. (1984) Abor Volcanics; Further Evidence for the Birth of Tethys Ocean in the Himalayan Segment. Journal of the Geological Society of London, 141, 763-775. https://doi.org/10.1144/gsjgs.141.4.0763

[50] Sarma, K.K. (1991) Geological Setting of the Ophiolites and Magmatic Arc of the Lohit Himalaya (Arunachal Pradesh), India with Special Reference to Their Petrochemistry. In: Geology and Geodynamic Evolution of the Himalayan Collision Zone, Physics and Chemistry of the Earth, Vol. 18, Pergamon Press PLC, Oxford, 277-292.

[51] Fairbridge, R.W. (Ed.) (1972) The Encyclopedia of Geochemistry and Environmental Sciences. Van Nostrand Reinhold Company, New York, 1344.

[52] Roy, D.K., Rahman, Md.M. and Akhther, S. (2006) Provenance of Exposed Tipam Sandstone Formation, Surma Basin, Sylhet, Bangladesh. Journal of Life and Earth Science, 1, 35-42.

[53] Lewan, M.D. and Maynards, J.B. (1982) Factors Controlling the Enrichment of Vanadium and Nickel in the Bitumen of Organic Sedimentary Rocks. Geochimica et Cosmochimica Acta, 46, 2547-2560. https://doi.org/10.1016/0016-7037(82)90377-5

[54] Erikson, K.A., Taylor, S.R. and Korsch, R.J. (1992) Geochemistry of 1.8 - 1.67 Ga Mudstones and Siltstones from the Mount Isa Inlier, Queensland, Australia: Provenance and Tectonic Implications. Geochimica et Cosmochimica Acta, 56, 899-909. https://doi.org/10.1016/0016-7037(92)90035-H

[55] Jones, B. and Manning, A.C. (1994) Comparison of Geochemical Indices Used for the Interpretation of Palaeo-Redox Conditions in Ancient Mudstones. Chemical Geology, 3, 111-129. https://doi.org/10.1016/0009-2541(94)90085-X

[56] Thong, G.T. and Rao, B.V. (2006) Geochemical Investigations of the Disang Sandstones of Bosta, Nagaland, NE India. Journal of the Geological Society of India, 68, 715-722.

[57] Hayashi, K., Gujisawa, H., Holland, H.D. and Ohmoto, H. (1997) Geochemistry of 1.9 Ga Sedimentary Rocks from Northeastern Labrador, Canada. Geochimica et Cosmochimica Acta, 61, 4115-4137. https://doi.org/10.1016/S0016-7037(97)00214-7

[58] McLennan, S.M., Nance, W.B. and Taylor, S.R. (1980) Rare Earth Element-Thorium Correlations in Sedimentary Rocks and the Composition of the Continental Crust. Geochimica et Cosmochimica Acta, 44, 1833-1839. https://doi.org/10.1016/0016-7037(80)90232-X

[59] Taylor, S.R. (1960) The Abundance of the Rare Earth Elements in Relation to Their Origin. Geochimica et Cosmochimica Acta, 19, 100-112. 
https://doi.org/10.1016/0016-7037(60)90041-7

[60] Cullers, R.L. and Graf, J.L. (1984) Rare Earth Elements in Igneous Rocks of the Continental Crust: Intermediate and Silicic Rocks-Ore Petrogenesis. In: Henderson, P., Ed., Rare Earth Element Geochemistry, Elsevier, Amsterdam, 275-316. https://doi.org/10.1016/B978-0-444-42148-7.50013-7

[61] Nagarajan, R., Armstrong-Attrin, J.S., Nagendra, R., Madhavaraju, J. and Moutte, J. (2007) Petrography and Geochemistry of Terrigenous Sedimentary Rocks in the Neoproterrozoic Rabanpalli Formation, Bhima Basin, Southern India: Implications for Palaeo-Weathering Conditions, Provenance and Source Rock Composition. Journal of the Geological Society of India, 70, 297-312.

[62] Taylor, S.R., Rudnick, R.L., McLennan, S.M. and Erickson, K.A. (1986) Rare Earth Element Patterns in Archean High Grade Metasediments and Their Tectonic Significance. Geochimica et Cosmochimica Acta, 50, 2267-2279.

https://doi.org/10.1016/0016-7037(86)90081-5

[63] Nesbitt, H.W., Young, G.M., McLennan, S.M. and Keays, R.R. (1996) Effects of Chemical Weathering and Sorting on the Petrogenesis of Siliclastic Sediments, with Implications for Provenance Studies. Journal of Geology, 104, 525-542. https://doi.org/10.1086/629850

[64] Bhatia, M.R. (1985) Rare Earth Element Geochemistry of Australian Palaeozoic Greywackes and Mudrocks: Provenance and Tectonic Control. Sedimentary Geolo$g y, 45,97-113$.

Submit or recommend next manuscript to SCIRP and we will provide best service for you:

Accepting pre-submission inquiries through Email, Facebook, LinkedIn, Twitter, etc. A wide selection of journals (inclusive of 9 subjects, more than 200 journals)

Providing 24-hour high-quality service

User-friendly online submission system

Fair and swift peer-review system

Efficient typesetting and proofreading procedure

Display of the result of downloads and visits, as well as the number of cited articles

Maximum dissemination of your research work

Submit your manuscript at: http://papersubmission.scirp.org/

Or contact ojg@scirp.org 